\title{
Psychoactive Substances of Natural Origin: Toxicological Aspects, Therapeutic Properties and Analysis in Biological Samples
}

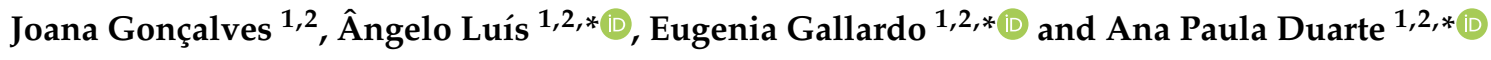 \\ 1 Centro de Investigação em Ciências da Saúde (CICS-UBI), Universidade da Beira Interior, Av. Infante D. \\ Henrique, 6200-506 Covilhã, Portugal; joanadgoncalves13@gmail.com \\ 2 Laboratório de Fármaco-Toxicologia, UBIMedical, Universidade da Beira Interior, Estrada Municipal 506, \\ 6200-284 Covilhã, Portugal \\ * Correspondence: angelo.luis@ubi.pt (Â.L.); egallardo@fcsaude.ubi.pt (E.G.); \\ apduarte@fcsaude.ubi.pt (A.P.D.); Tel.: +351-275-329-002/3 (Â.L. \& E.G. \& A.P.D.)
}

Citation: Gonçalves, J.; Luís, Â.;

Gallardo, E.; Duarte, A.P.

Psychoactive Substances of Natural Origin: Toxicological Aspects,

Therapeutic Properties and Analysis in Biological Samples. Molecules 2021, 26, 1397. https://doi.org/10.3390/ molecules 26051397

Academic Editor: Lillian Barros

Received: 10 February 2021

Accepted: 2 March 2021

Published: 5 March 2021

Publisher's Note: MDPI stays neutral with regard to jurisdictional claims in published maps and institutional affiliations.

Copyright: (c) 2021 by the authors. Licensee MDPI, Basel, Switzerland. This article is an open access article distributed under the terms and conditions of the Creative Commons Attribution (CC BY) license (https:/ / creativecommons.org/licenses/by/ $4.0 /)$.

\begin{abstract}
The consumption of new psychoactive substances (NPSs) has been increasing, and this problem affects several countries worldwide. There is a class of NPSs of natural origin, consisting of plants and fungi, which have a wide range of alkaloids, responsible for causing relaxing, stimulating or hallucinogenic effects. The consumption of some of these substances is prompted by religious beliefs and cultural reasons, making the legislation very variable or even ambiguous. However, the abusive consumption of these substances can present an enormous risk to the health of the individuals, since their metabolism and effects are not yet fully known. Additionally, NPSs are widely spread over the internet, and their appearance is very fast, which requires the development of sophisticated analytical methodologies, capable of detecting these compounds. Thus, the objective of this work is to review the toxicological aspects, traditional use/therapeutic potential and the analytical methods developed in biological matrices in twelve plant specimens (Areca catechu, Argyreia nervosa, Ayahuasca, Catha edulis, Datura stramonium, Lophophora williamsii, Mandragora officinarum, Mitragyna speciosa, Piper methysticum Forst, Psilocybe, Salvia divinorum and Tabernanthe iboga).
\end{abstract}

Keywords: NPS of natural origin; psychoactive effects; toxicological aspects; traditional uses; analytical methodologies

\section{Introduction}

The use of drugs of abuse is a concern that has been increasing over the years. About 96 million individuals have already used drugs of abuse in the European Union, cannabis being the most used (27.4\%), followed by cocaine $(5.4 \%)$ and then ecstasy $(4.1 \%)$ and amphetamines (3.7\%) [1]. In recent years, a trend of new psychoactive substance (NPS) consumption has been reported. The European Monitoring Center for Drugs and Drug Addiction (EMCDDA) defines those compounds as "a new narcotic or psychotropic drug, in pure form or in preparation, that is not controlled by the United Nations Drug Conventions, but which may pose a public health threat comparable to that posed by substances listed in these conventions" [2]. NPSs have spread around the world, mainly because they are marketed on the internet in dark web forums, with different names, namely "bath salts", "legal highs", or "research chemicals" [3]. These substances are generally consumed because they are able to mimic the effects of more conventional drugs of abuse and because they are not detected in common screening methods [4-6]. However, the various risks associated with the consumption of NPSs are described in the literature, as well as the resulting health problems [7-9].

Despite the term "new" referring to a recent appearance, the truth is that some of these compounds have existed for decades, but they only became available on the market more 
recently, and consequently, their commercialization is not yet regulated [3]. The constant appearance of these drugs (about 50 new per year) is a concern in terms of controlling their marketing [1]. Additionally, considering the health hazard presented by NPSs, the United Nations Office on Drugs and Crime (UNODC) and the EMCDDA have implemented early warning systems in order to detect these compounds [10,11].

NPSs may have a synthetic or natural origin, the most recognized synthetic NPS being synthetic cannabinoids, cathinones and opioids, piperazines, phenethylamines, designer benzodiazepines, indoalkylamines and arylcyclohexylamines [2-4]. NPSs of natural origin consist mainly of alkaloids naturally present in plants that, when consumed, allow the user to experience new sensations and different "mental states" [3,12]. These plants come mainly from South America and Asia but also from Africa and Russia [3] and, depending on their constituents, can trigger relaxing and/or sedative effects, such as Areca catechu (A. catechu) and Mitragyna speciosa (M. speciosa), hallucinogenic effects, as the constituents of Ayahuasca, or stimulating effects, such as Catha edulis (C. edulis) $[3,13]$. The consumption of preparations containing alkaloids of natural origin is often prompted by religious beliefs or cultural reasons, making it difficult to estimate the worldwide consumption of these substances [3]. For these reasons, the legislation that regulates these substances is quite variable and may even be ambiguous [2].

The metabolism of these substances is not fully studied, and therefore the resulting metabolites and their potential concentrations are not known [2,3]. Another gap that needs further study is the acute toxicity of many of these substances, which are also not completely known [2]. In fact, the symptoms described during intoxication with an NPS are confused with symptoms of consumption of other substances, namely medicines [2]. Thus, developing analytical methodologies is greatly important for the detection and quantification of potentially dangerous compounds present in these natural products. However, most developed analytical methods have focused on the detection of alkaloids naturally present in plant materials [14].

In this review, we sought to address the toxicological aspects of several psychoactive substances present in different plants, as well as some therapeutic properties/traditional uses. In addition, the analytical methods developed in biological samples aimed at the detection of psychoactive substances from the same plants were also discussed.

\section{Areca catechu (Betel Quid)}

Currently, A. catechu (Figure 1A) is distributed in Africa, Europe and America, in spite of its main origin being Asia (Sri Lanka and Malaysia) [2]. The areca nut is the fruit produced by this plant, having been consumed for centuries as a traditional remedy or in rituals [15]. This fruit is normally chewed and can be consumed together with other substances in the form of a "betel quid" $[15,16]$. Areca nut is the fourth drug with the highest consumption rate worldwide, possibly due to its stimulating, relaxing or aphrodisiac effects $[15,16]$. Arecoline (Figure 1B) is the main psychoactive compound present in the fruit of $A$. catechu [2]. This compound is an alkaloid that works as a competitive inhibitor of gamma-aminobutyric acid (GABA) and as a non-selective nicotinic and muscarinic agonist $[3,17,18]$. Once in the body, arecoline quickly crosses the blood-brain barrier, exerting effects on the parasympathetic nervous system [3]. However, this fruit is addictive and can cause several adverse effects, namely on the digestive system and abstinence syndrome (insomnia, mood swings, irritability and anxiety) [3,15]. Other effects, such as severe extrapyramidal syndrome, asthma and myocardial infarction, have also been associated with the consumption of this fruit $[19,20]$. However, the use of this fruit for medicinal purposes has also been described, since antiquity, by Hindu and Buddhist peoples [21]. The consumption of areca nut has been associated with general properties such as satisfaction, well-being, psychostimulating effects, stress reduction, gum strengthening and breath sweetening [21]. Additionally, this fruit is used in the treatment of malaria, fever, hernia, hypertension, urinary stones and in the manufacture of formulations for the treatment of digestive diseases, diarrhea and indigestion [21]. Studies have also indicated that the 
consumption of areca nut is associated with antimicrobial [22,23], cardiovascular [23,24] and digestive effects [21,23-25]. In addition to the $A$. catechu fruit, roots and leaves were also traditionally used in medicine [21].

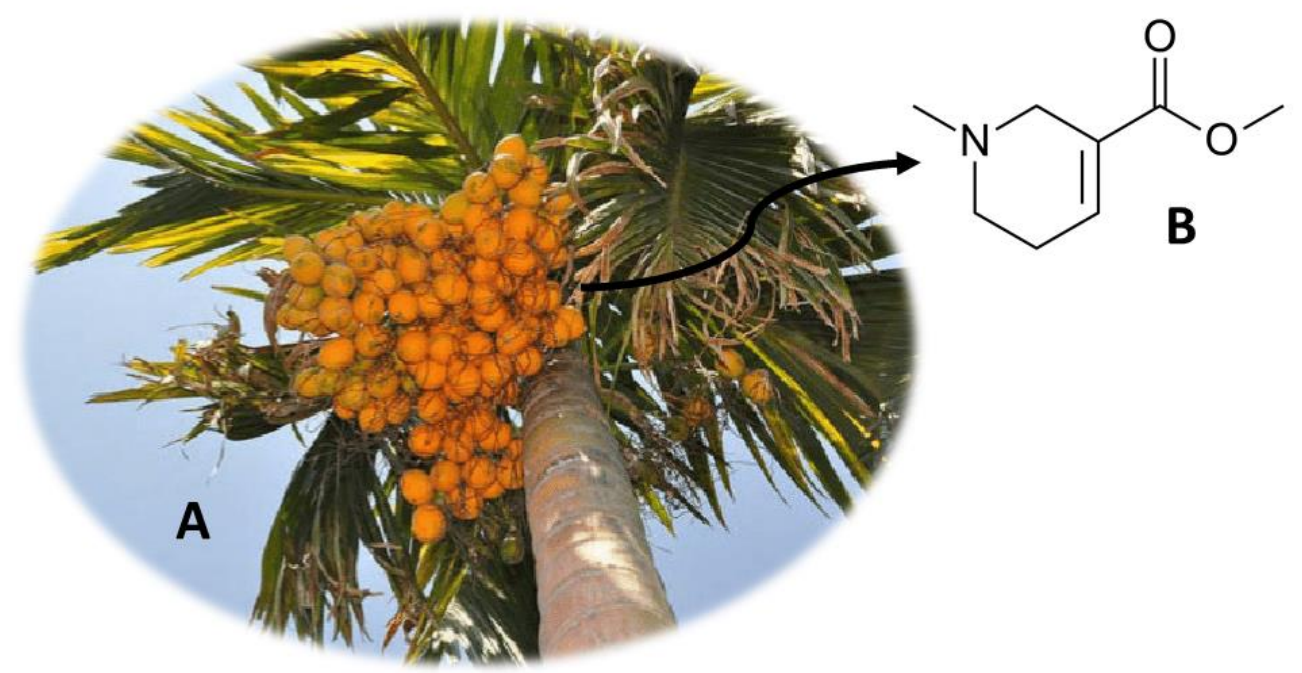

Figure 1. A. catechu (A) and the main compound arecoline (B).

A. catechu and its fruit are not controlled substances, and therefore there is no legislation for their consumption in the United States of America and in the European Union [3]. Thus, several analytical methods, which allow the measurement of these substances, have been developed (Table 1). Conventional samples, such as blood, continue to be used for the detection of the most diverse compounds, including arecoline [26]. Wu et al. [26] developed an analytical method where they proceeded to quantify arecoline in an LC-MS/MS equipment, using $1 \mathrm{~mL}$ of blood, obtaining a limit of detection (LOD) of $0.02 \mathrm{ng} / \mathrm{mL}$ and a limit of quantification (LOQ) of $0.5 \mathrm{ng} / \mathrm{mL}$. Urine is another biological matrix that has been used for the measurement of arecoline [27]. Pichini et al. [27] developed an analytical method in HPLC-MS equipment, where they used $1 \mathrm{~mL}$ of urine, having managed to quantify arecoline. In the same study, it was also possible to quantify the same compound in samples of meconium $(1 \mathrm{~g})$ and cord serum $(1 \mathrm{~mL})$ [27]. However, other alternative samples, such as teeth [28], saliva [29,30] and breast milk [31] have been also used in the development of new analytical methods for detecting arecoline. Pellegrini et al. [31] developed a method for the determination of arecoline in LC-MS/MS, using $1 \mathrm{~mL}$ of breast milk. This method had a LOD of $16 \mathrm{ng} / \mathrm{mg}$ and LOQ of $50 \mathrm{ng} / \mathrm{mg}$ [31]. 
Table 1. Analytical methods for the determination of the main components of Areca catechu.

\begin{tabular}{|c|c|c|c|c|c|c|c|}
\hline Compounds & $\begin{array}{l}\text { Sample } \\
\text { (Amount) }\end{array}$ & $\begin{array}{c}\text { Sample } \\
\text { Preparation }\end{array}$ & $\begin{array}{l}\text { Analytical } \\
\text { Technique }\end{array}$ & $\begin{array}{l}\text { Limits of } \\
\text { Detection }\end{array}$ & $\begin{array}{c}\text { Limits of } \\
\text { Quantitation }\end{array}$ & Recovery (\%) & Reference \\
\hline Arecoline & Teeth (50 mg) & $\begin{array}{l}\text { Pulverization and } \\
\text { sonica- } \\
\text { tion (methanol) }\end{array}$ & $\begin{array}{c}\text { LC-MS/MS } \\
\text { (ESI); LC-HR- } \\
\text { ToF-MS } \\
\text { (ESI) }\end{array}$ & - & - & - & [28] \\
\hline Arecoline & Saliva (950 mL) & $\begin{array}{l}\text { LLE (ethylacetate) } \\
\text { Pulverization; }\end{array}$ & HPLC-UV-VIS & - & - & - & [29] \\
\hline Arecoline & Hair (50 mg) & $\begin{array}{c}\text { alkaline digestion } \\
\text { (NaOH } 12 \mathrm{M} \text { ) and } \\
\text { LLE (cloro- } \\
\text { form/isopropanol } \\
(95: 5, v / v)\end{array}$ & LC-MS (ESI) & $0.09 \mu \mathrm{g} / \mathrm{g}$ & $0.3 \mu \mathrm{g} / \mathrm{g}$ & $81.2 \pm 2.6$ & [32] \\
\hline Arecoline & $\begin{array}{c}\text { Meconium } \\
(1000 \mathrm{mg}), \\
\text { urine }(1 \mathrm{~mL}) \\
\text { and cord } \\
\text { serum }(1 \mathrm{~mL})\end{array}$ & $\begin{array}{l}\text { LLE (chloro- } \\
\text { form/isopropanol } \\
(95: 5, v / v))\end{array}$ & LC-MS (ESI) & $\begin{array}{c}0.0004-0.001 \\
\mu \mathrm{g} / \mathrm{g}\end{array}$ & $\begin{array}{l}0.001-0.005 \\
\mu \mathrm{g} / \mathrm{g}\end{array}$ & $86.5-90.7$ & [27] \\
\hline Arecoline & $\begin{array}{l}\text { Breast milk } \\
\quad(1 \mathrm{~mL})\end{array}$ & $\begin{array}{l}\text { LLE (chloro- } \\
\text { form/isopropanol } \\
(95: 5, v / v))\end{array}$ & $\begin{array}{l}\text { LC-MS/MS } \\
\text { (ESI) }\end{array}$ & $16 \mu \mathrm{g} / \mathrm{L}$ & $50 \mu \mathrm{g} / \mathrm{L}$ & $76.8-84.7$ & [31] \\
\hline $\begin{array}{c}\text { Arecoline, } \\
\text { Arecaidine and } \\
\mathrm{N}- \\
\text { methylnipecotic } \\
\text { acid }\end{array}$ & $\begin{array}{l}\text { Saliva } \\
(0.05 \mathrm{~mL})\end{array}$ & PP (acetonitrile) & $\begin{array}{l}\text { LC-MS/MS } \\
\text { (ESI) }\end{array}$ & $0.156 \mu \mathrm{g} / \mathrm{L}$ & $1.25 \mu \mathrm{g} / \mathrm{L}$ & $72.5-100.1$ & [30] \\
\hline
\end{tabular}

Caption: ESI (electrospray ionization); HPLC (high-performance liquid chromatography); HR (high resolution); LC (liquid chromatography); LLE (liquid-liquid extraction); MS (mass spectrometry); MS/MS (tandem mass spectrometry); PP (protein precipitation); ToF (time of flight); UV-VIS (ultraviolet-visible detector).

\section{Argyreia nervosa (Adhoguda)}

A. nervosa (Figure 2A) is originally from India, but it is widely distributed in Europe, Africa and subtropical America [33]. This plant, also known as Adhoguda, Vidhara, Elephant Creeper, Rivea corymbosa, Hawaiian Baby Woodrose or Morning Glory or Ipomoea violacea, possesses psychoactive alkaloids in its seeds [3]. Isoergine (Figure 2B) and lysergamide (LSA) (Figure 2C) are the compounds responsible for the hallucinogenic properties of this plant, being able to induce effects similar to lysergic acid diethylamide (LSD), albeit with a lower intensity [34]. A. nervosa seeds have a total of ergoline alkaloids between $0.5 \%$ and $0.9 \%$, of which $0.19 \%$ correspond to isoergine and $0.14 \%$ correspond to LSA [35]. The LSA exerts its effects by binding to dopamine D2 receptors and consequent inhibition of adenylate cyclase and reduction in the production of cyclic adenosine monophosphate (cAMP) [36]. The consumption of this plant for medicinal purposes has also been described, namely as a diuretic and aphrodisiac [13]. Analgesic, anti-inflammatory, immunomodulatory, hepatoprotective and hypoglycemic properties have also been described $[13,37]$. A. nervosa roots are also used in the treatment of diseases of the central nervous system, rheumatism, gonorrhea and chronic ulcer. On the other hand, antimicrobial activity has been associated with the plant leaf $[13,37]$. In addition to the two alkaloids already mentioned, others have been also isolated from plants, namely erginine, ergometrine, lysergol, peniclavine, chanoclavin I, chanoclavin II, ergometrinine, elimoclavin and egine, but their effects are not yet known [38]. 


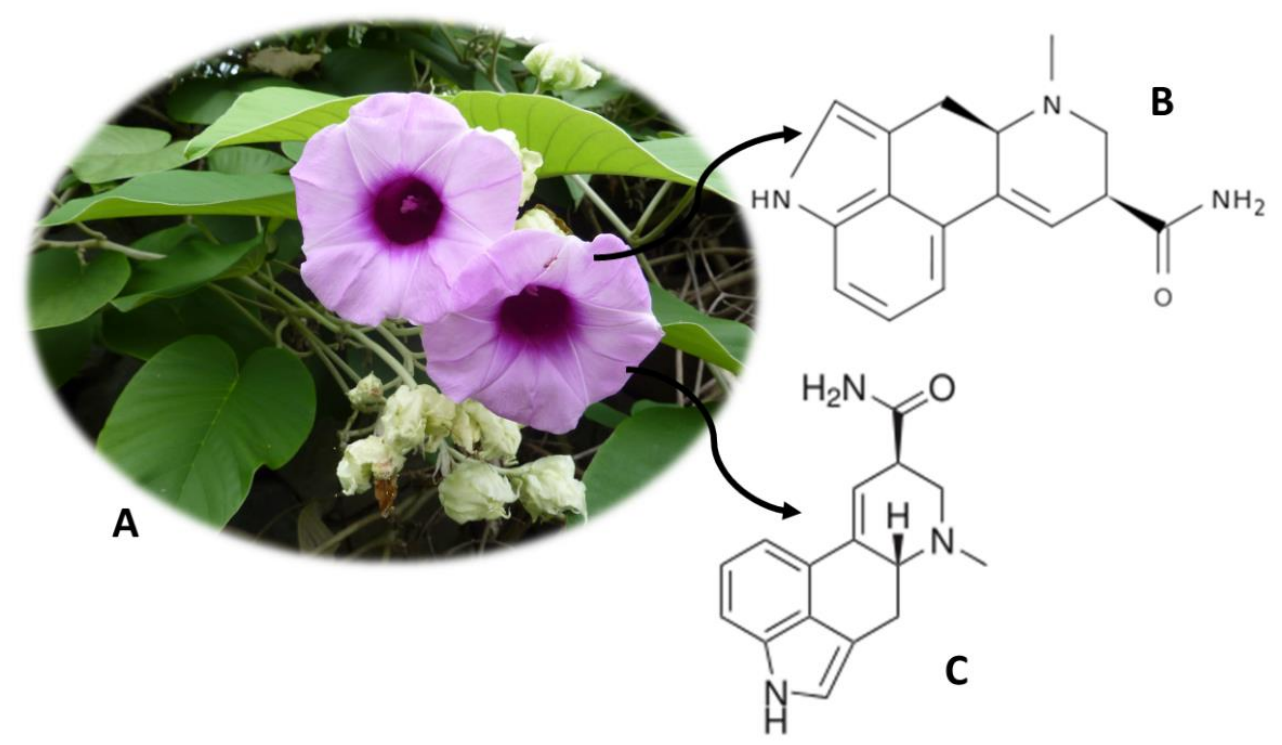

Figure 2. Argyreia nervosa (A) and the main compounds isoergine (B) and lysergamide (LSA) (C).

LSA is a controlled substance in some European countries, namely in the United Kingdom and Italy. It is also controlled in the United States of America, but the plant and its seeds are freely sold [3]. There are currently analytical methodologies developed that allow quantifying the LSA. Paulke et al. [39] developed an analytical method, with $1 \mathrm{~mL}$ of serum and urine, to detect and quantify LSA. The analytes were extracted using the SPE (solid-phase extraction) technique and quantified on HPLC-FLD equipment [39]. The method had detection and quantification limits of $0.05-0.15 \mathrm{ng} / \mathrm{mL}$ and $0.17 \mathrm{ng} / \mathrm{mL}$, respectively, and recoveries between $69.4 \%$ and $78.8 \%$ [39].

\section{Ayahuasca ("Hoasca")}

Ayahuasca is a word of Quechua origin, composed of two terms: "aya" and "waska", which mean "spirit" and "vine", respectively [40]. On its whole, the word Ayahuasca means "rope of the soul", and it is also known as caapi, daime, hoasca, yagé and natema [3,40]. This term refers to a psychoactive drink, traditional in South America (Figure 3A). More recently, it has been imported into some countries in Europe and Asia [3,41,42]. Ayahuasca consists of a brown, thick and oily liquid, the result of a decoction of shavings from the stem of Banisteriopsis caapi (B. caapi) and leaves of Psychotria viridis (P. viridis) (Figure 3B) [41,42]. Additionally, other species of natural origin, which replace those already mentioned, can be used in the preparation of Ayahuasca, namely Brugmansia suaveolens, Psychotria carthagenensis, Nicotiana tabacum, Tabernaemontana spp., Brunfelsia spp., Datura suaveolens, Iochroma fuchsioides, Malouetia tamarquina, Juanulloa spp. and Peganum harmala, among other products with hallucinogenic compounds [43]. 


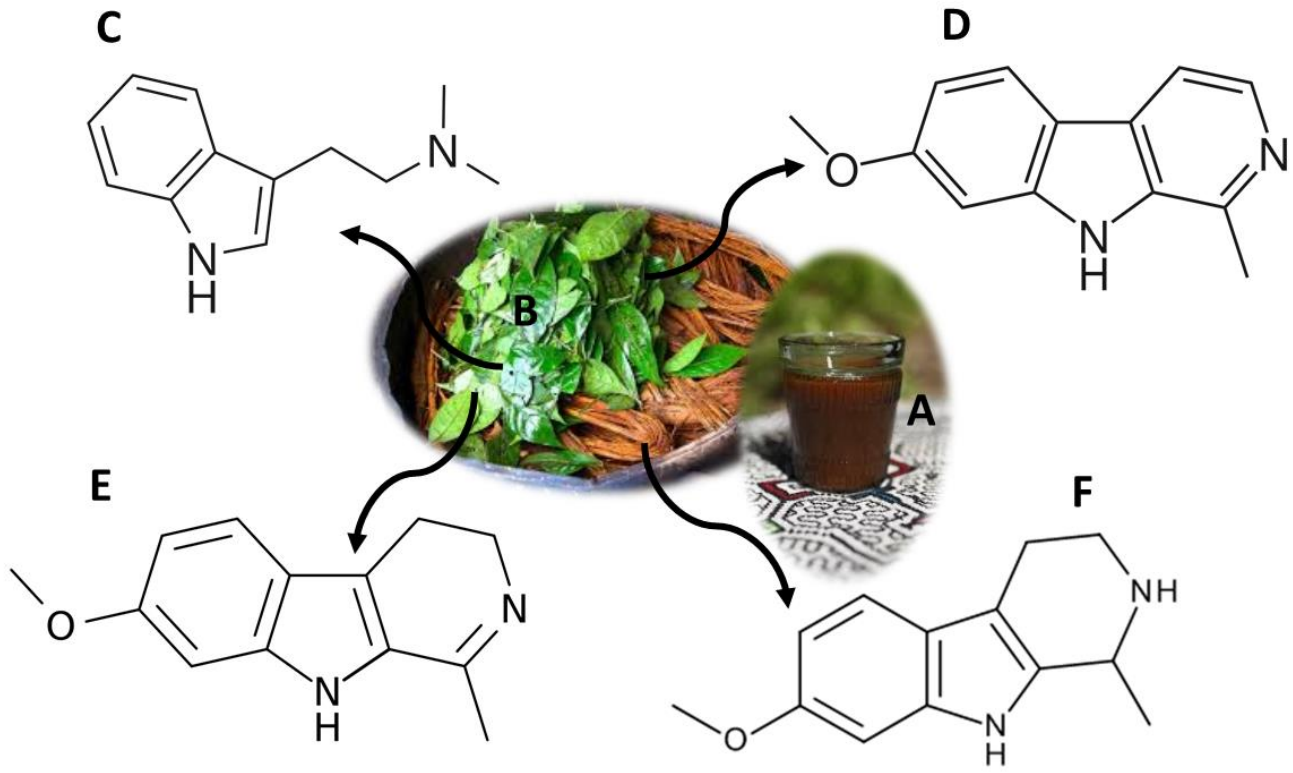

Figure 3. Ayahuasca decoction (A); Banisteriopsis caapi stem shavings and Psychotria viridis leaves used in the preparation of the Ayahuasca beverage (B); main compounds present in Ayahuasca: DMT (C), Harmine (D), Harmaline (E) and THH (F).

The effects of this psychoactive mixture are due to the synergy potential of N,Ndimethyltryptamine (DMT) (Figure 3C), a hallucinogenic compound from P. viridis, and of the harmine (Figure 3D), harmaline (Figure 3E) and tetrahydroharmine (THH) (Figure 3F), which are $\beta$-carbolinic alkaloids present in B. caapi $[44,45]$. DMT is a tryptamine that acts as an agonist for serotonin receptors (5-HT1A/2A/2C) [3]. When this compound is ingested alone, it undergoes metabolism by peripheral monoamine oxidase $\mathrm{A}$ (MAO-A), being inactive [46]. However, when DMT is ingested together with $\beta$-carbolinic alkaloids, it is able to penetrate the central nervous system, since it temporarily inhibits MAOA [44,46-48]. In addition, THH also inhibits serotonin reuptake by increasing the effects of DMT [49]. Users describe visual hallucinations, with effects on temperature, pupil size and changes in the endocrine, cardiovascular and immune systems [3,50]. Side effects such as mydriasis, vomiting, hypertension, tachycardia, agitation, paranoia, anxiety and depression have also been described $[3,50,51]$. However, there are several studies that report therapeutic properties. Recently their proprieties were reported as antimicrobial and antioxidant agents [52], as well as their effect over dopaminergic neuron cells [53]. Studies have shown that a single dose of Ayahuasca leads to a rapid reduction in depressive symptoms, and this reduction is maintained for three weeks [54,55]. Other studies show that the consumption of this decoction results in a significant reduction in anxiety and panic [54,56]. The reduction of drug and alcohol abuse [57-59], attention problems [60] and decreased physical pain, fatigue, insomnia, irritability and obsession [61] have also been described.

Ayahuasca has been used in religious rituals in the Amazon for centuries, and more recently by religious entities such as União do Vegetal (UDV) and Santo Daime [3,40]. DMT-containing substances are controlled in the United States of America and in some European countries [3]. However, the consumption of P. viridis and B. caapi is not controlled, and the use of Ayahuasca for religious purposes is legal in the United States of America and Brazil [3]. There are currently several analytical methodologies that allow the detection and quantification of the compounds from Ayahuasca and its metabolites (Table 2). The samples of choice for the quantification of these compounds are the so-called conventional samples, namely blood [62], plasma [63,64] and urine [65,66]. Yritia et al. [63] and Oliveira et al. [64] developed analytical methods for the detection of DMT and $\beta$-carbolines, using $1 \mathrm{~mL}$ of plasma. Both methods used SPE $[63,64]$ as a sample pre-treatment technique, and in the first 
study, a liquid-liquid extraction (LLE) was also performed [63]. Both studies showed good limits of detection and quantification, as well as good recoveries [63,64]. More recently, Pichini et al. [67] carried out a study, where they quantified DMT, using only $25 \mathrm{mg}$ of hair. The hair sample was initially hydrolyzed with an M3 reagent, and HPLC-MS-MS equipment was used to quantify the analyte [67]. The LOD varied between $0.01 \mathrm{ng} / \mathrm{mg}$ and $0.02 \mathrm{ng} / \mathrm{mg}$ and the LOQ between $0.03 \mathrm{ng} / \mathrm{mg}$ and $0.05 \mathrm{ng} / \mathrm{mg}$, with recoveries between $76.6 \%$ and $97.4 \%$ [67].

Table 2. Analytical methods for the determination of the main components of Ayahuasca.

\begin{tabular}{|c|c|c|c|c|c|c|c|}
\hline Compounds & $\begin{array}{c}\text { Sample } \\
\text { (Amount) }\end{array}$ & Sample Preparation & $\begin{array}{l}\text { Analytical } \\
\text { Technique }\end{array}$ & $\begin{array}{l}\text { Limits of } \\
\text { Detection }\end{array}$ & $\begin{array}{c}\text { Limits of } \\
\text { Quantitation }\end{array}$ & Recovery (\%) & Reference \\
\hline $\begin{array}{c}\text { 5-OH-DMT, } \\
\text { DMK, Harmol, } \\
\text { Harmalol, } \\
\text { NMT, } \\
\text { 5-MeO-DMT, } \\
\text { 2-MTHBC, } \\
\text { THH, } \\
\text { DMT-NO, } \\
\text { Harmine and } \\
\text { Harmaline }\end{array}$ & Urine $(0.1 \mathrm{~mL})$ & $\begin{array}{l}\text { Dilution (90\% water- } \\
0.1 \% \text { formic acid:10\% } \\
\text { acetonitrile-0.1\% } \\
\text { formic acid) and } \\
\text { enzyme hydrolysis } \\
\text { (glucuronidase- } \\
\text { sulfatase- } \\
\text { acetate buffer) }\end{array}$ & $\begin{array}{l}\text { LC-MS/MS } \\
\text { (ESI) }\end{array}$ & $0.04-0.57 \mu \mathrm{g} / \mathrm{L}$ & $5 \mu \mathrm{g} / \mathrm{L}$ & - & [65] \\
\hline $\begin{array}{l}\text { DMT, Harmine, } \\
\text { Harmaline, } \\
\text { THH, } \\
\text { Harmol and } \\
\text { Harmalol }\end{array}$ & Plasma (1 mL) & $\begin{array}{l}\text { LLE (n-pentane) and } \\
\text { SPE }\left(C_{18}\right)\end{array}$ & $\begin{array}{c}\text { GC-NPD } \\
\text { and } \\
\text { HPLC-FLD }\end{array}$ & - & $0.3-1.6 \mu \mathrm{g} / \mathrm{L}$ & $74-87$ & [63] \\
\hline $\begin{array}{c}\text { DMT, Harmine, } \\
\text { Harmaline, } \\
\text { THH, } \\
\text { Harmol, } \\
\text { Harmalol, } \\
\text { 5-OH-DMT, } \\
\text { THH-OH, } \\
\text { DMK, NMT, } \\
\text { 5-MeODMT, } \\
\text { 2-MTHBC, } \\
\text { DMT-NO }\end{array}$ & Blood (0.2 mL) & $\begin{array}{l}\text { PP (96-well plates), } \\
\text { Dilution (formic acid } \\
(0.1 \% \text { in water); } \\
\text { formic acid }(0.1 \% \\
\text { inacetonitrile) })\end{array}$ & $\begin{array}{l}\text { LC-MS/MS } \\
\text { (HESI) }\end{array}$ & $0.09-0.45 \mu \mathrm{g} / \mathrm{L}$ & $1.0 \mu \mathrm{g} / \mathrm{L}$ & $60.28-76.31$ & {$[62]$} \\
\hline $\begin{array}{l}\text { DMT, Harmine, } \\
\text { Harmaline, } \\
\text { THH }\end{array}$ & Plasma (1 mL) & $\operatorname{SPE}\left(\mathrm{C}_{18}\right)$ & $\begin{array}{c}\mathrm{LC}-\mathrm{MS} / \mathrm{MS} \\
\text { (ESI) }\end{array}$ & $0.1 \mu \mathrm{g} / \mathrm{L}$ & $0.2-0.4 \mu \mathrm{g} / \mathrm{L}$ & 88.4-107.7 & {$[64]$} \\
\hline DMT & Hair (25 mg) & $\begin{array}{l}\text { Hydrolysis (M3 } \\
\text { reagent) }\end{array}$ & $\begin{array}{l}\text { UHPLC- } \\
\text { MS/MS } \\
\text { (ESI) }\end{array}$ & $\begin{array}{l}0.01-0.02 \\
\mu \mathrm{g} / \mathrm{g}\end{array}$ & $\begin{array}{c}0.03-0.05 \\
\mu \mathrm{g} / \mathrm{g}\end{array}$ & $79.6-97.4$ & {$[67]$} \\
\hline $\begin{array}{l}\text { DMT and } \\
\text { DMT-NO }\end{array}$ & Urine $(0.1 \mathrm{~mL})$ & $\begin{array}{l}\text { Dilution }(97: 3 \text { water } \\
\text { with } 0.1 \% \text { formic } \\
\text { acid:acetonitrile with } \\
0.1 \% \text { formic acid) }\end{array}$ & $\begin{array}{l}\text { LC-MS/MS } \\
\text { (ESI) }\end{array}$ & - & $5.0 \mu \mathrm{g} / \mathrm{L}$ & - & {$[66]$} \\
\hline
\end{tabular}

Caption: ESI (electrospray ionization); FLD (fluorescence detector); GC (gas chromatography); HESI (heated electrospray); HPLC (highperformance liquid chromatography); LC (liquid chromatography); LLE (liquid-liquid extraction); MS/MS (tandem mass spectrometry); NPD (nitrogen-phosphorus detector); PP (protein precipitation); SPE (solid-phase extraction); UHPLC (ultrahigh-performance liquid chromatography).

\section{Catha edulis (Khat)}

C. edulis (Figure 4A) comes from some West African countries, as well as from Yemen, Ethiopia and the Arabian Peninsula [2]. This plant is often used as a drug of abuse since it allows to mimic the effects of synthetic cathinones but with a lower risk of intoxication, with no record of deaths associated with its consumption [2]. C. edulis is also called khat, qat and kafta, among others, and it is usually consumed in smoked form or by chewing fresh leaves [3]. The psychoactive components present in the leaves of this plant are S-(-)-cathinone (Figure 4B), cathine ([S,S-(+)-norpseudoephedrine]) (Figure 4C) and phenylpropanolamine (Figure 4D). S-(-)-cathinone is photosensitive, and therefore it degrades easily with sun exposure, being the major compound in fresh khat leaves, but it is not found in older leaves [68]. After sun exposure, S-(-)-cathinone degrades into chatine and (-)-norephedrine, these being the compounds present mostly in the older leaves [68]. When consuming khat, the active compounds degrade not only into chatine and (-)norephedrine but also into [R,S-(-)-norephedrine] and [R,R-(-)-norpseudoephedrine], 
compounds structurally similar to amphetamine [69]. Consumers of this plant describe effects such as hyperthermia, euphoria, increased breathing and sensory stimulation, excitation and anorexia. However, adverse effects such as violent behavior, schizophrenia, paranoia and psychosis, increased blood pressure, insomnia, tachycardia, irritability, migraine and sexual dysfunction have also been described [3].

The consumption and trade of khat leaves are not regulated by any international system, but the consumption and trade of cathinone and cathine are prohibited worldwide [3]. In some countries, khat is considered a controlled substance, namely Ireland, France, Germany, Denmark and the United States of America. In the Netherlands, its trade is not prohibited, but is restricted and, in Canada, the possession of khat is allowed, but its import and trade are also illegal [3]. On the other hand, countries like Yemen, Somalia and Ethiopia allow the consumption of khat, since it is a cultural habit [3].

There are currently analytical methodologies developed that allow quantifying the compounds present in khat (Table 3). Sørensen [70] developed an analytical method to quantify 15 compounds, using LC-MS/MS equipment with only $300 \mu \mathrm{L}$ of blood. The sample was treated with methanol to precipitate proteins, and then it was filtered [70]. The analytical method showed recoveries between $87 \%$ and $106 \%$ and a LOD between $0.5 \mathrm{ng} / \mathrm{mL}$ and $3 \mathrm{ng} / \mathrm{mL}$ [70]. In addition, samples such as plasma [71], urine [72] and oral fluid [73] were used to quantify these compounds. Mohamed et al. [73] used $500 \mu \mathrm{L}$ of oral fluid to quantify cathine, methcathinone, cathinone and ephedrine. The samples were submitted to an LLE (ethyl acetate) extraction technique and subsequently analyzed by GC-MS. The analytical method showed a LOQ of $20 \mathrm{ng} / \mathrm{mL}$ and a LOD of $10 \mathrm{ng} / \mathrm{mL}$ [73].

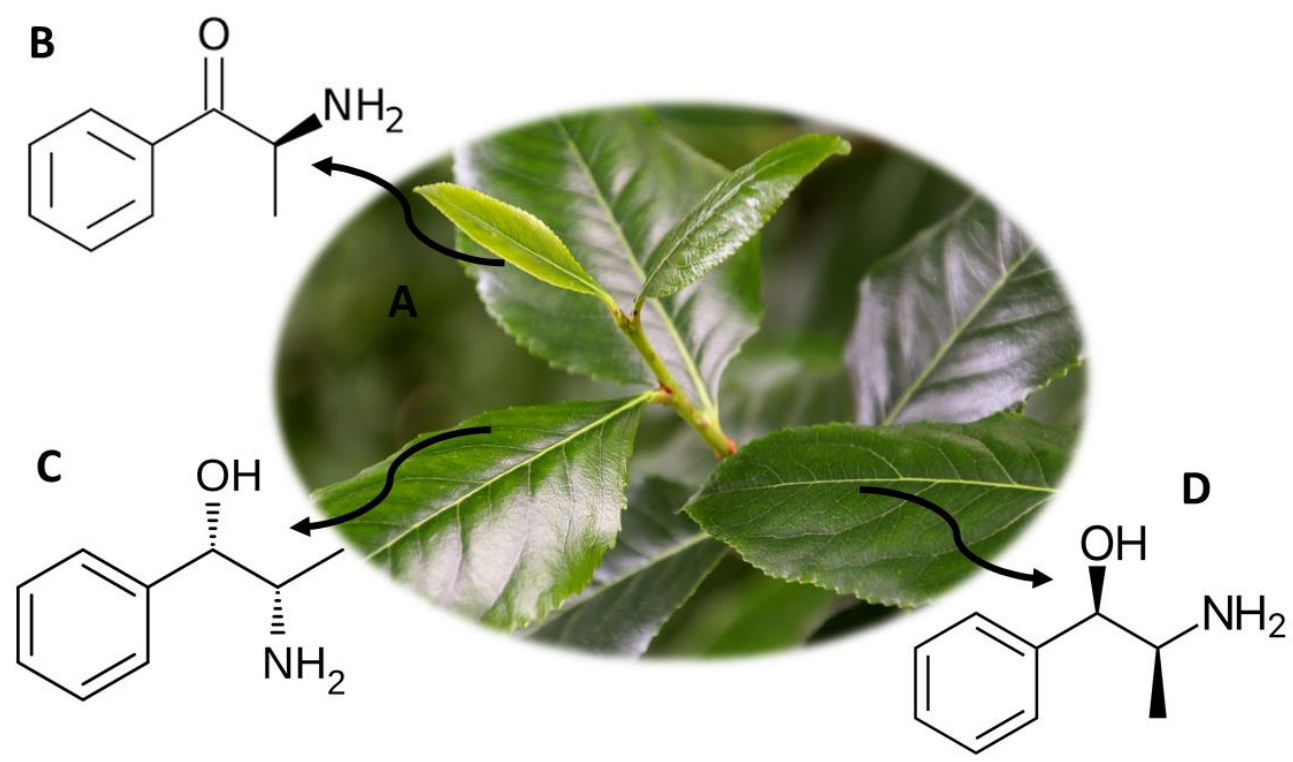

Figure 4. C. edulis (A) and the main compounds S-(-)-cathinone (B), cathine ([S,S-(+)-norpseudoephedrine]) (C) and phenylpropanolamine (D). 
Table 3. Analytical methods for the determination of the main components of Catha edulis.

\begin{tabular}{|c|c|c|c|c|c|c|c|}
\hline Compounds & $\begin{array}{l}\text { Sample } \\
\text { (Amount) }\end{array}$ & $\begin{array}{c}\text { Sample } \\
\text { Preparation }\end{array}$ & $\begin{array}{l}\text { Analytical } \\
\text { Technique }\end{array}$ & $\begin{array}{l}\text { Limits of } \\
\text { Detection }\end{array}$ & $\begin{array}{c}\text { Limits of } \\
\text { Quantitation }\end{array}$ & $\begin{array}{l}\text { Recovery } \\
(\%)\end{array}$ & Reference \\
\hline $\begin{array}{l}\text { Cathinone, } \\
\text { Cathine and Phenylpropanolamine }\end{array}$ & Urine $(0.2 \mathrm{~mL})$ & $\operatorname{SPE}\left(\mathrm{C}_{8}\right)$ & GC-MS (EI) & $<10 \mu \mathrm{g} / \mathrm{L}$ & - & $73-82$ & {$[72]$} \\
\hline $\begin{array}{c}\text { d-cathine (d-norpseudoehedrine), } \\
\text { ephedrine, methcathinone, 1-(4- } \\
\text { methoxyphenyl)-propan-2-amine, } \\
\text { mephedrone, methedrone, 2,5- } \\
\text { dimethoxy-4-methylamphetamine, } \\
\text { 4-bromo-2,5- } \\
\text { dimethoxyamphetamine, } \\
\text { 2,5-dimethoxyphenethylamine, } \\
\text { 4-bromo-2,5- } \\
\text { dimethoxyphenethylamine, } \\
\text { 4-iodo-2,5- } \\
\text { dimethoxyphenethylamine, } \\
\text { 2-[2,5-dimethoxy-4- } \\
\text { (ethylthio)phenyl]ethanamine, } \\
\text { 2,5-dimethoxy-4- } \\
\text { isopropylthiophenethylamine and } \\
\text { 2-[2,5-dimethoxy-4- } \\
\text { (propylthio)phenyl]ethanamine }\end{array}$ & $\begin{array}{l}\text { vitreous humor } \\
(0.1 \mathrm{~mL}) \\
\text { pericardial fluid } \\
(0.25 \mathrm{~mL}) \text { and } \\
\text { whole blood } \\
(0.25 \mathrm{~mL})\end{array}$ & $\begin{array}{c}\mathrm{SPE} \\
\left(\text { Oasis }{ }^{\circledR} \mathrm{MCX}\right)\end{array}$ & GC-MS (EI) & $5 \mu \mathrm{g} / \mathrm{L}$ & $5 \mu \mathrm{g} / \mathrm{L}$ & 100 & [74] \\
\hline $\begin{array}{l}\text { Cathinone, Methcathinone, } \\
\text { Ethcathinone, Amfepramone, } \\
\text { Mephedrone, Flephedrone, } \\
\text { Methedrone, Methylone, } \\
\text { Butylone, Cathine, Norephedrine, } \\
\text { Ephedrine, Pseudoephedrine, } \\
\text { Methylephedrine and } \\
\text { Methylpseudoephedrine }\end{array}$ & Blood (0.3 mL) & $\begin{array}{l}\mathrm{PP} \text { (methanol) } \\
\quad \text { and } \\
\text { Ultrafiltration }\end{array}$ & $\begin{array}{l}\text { LC-MS/MS } \\
\text { (ESI) }\end{array}$ & $0.5-3 \mu \mathrm{g} / \mathrm{L}$ & - & $87-106$ & {$[70]$} \\
\hline $\begin{array}{c}\text { cathinone, flephedrone, } \\
\text { buphedrone, 4-MTA, } \alpha \text {-PVP, } \\
\text { methylone, 2C-P, ethylone, } \\
\text { pentylone, MDPV and } \\
\text { bromo-dragonFLY }\end{array}$ & $\begin{array}{l}\text { whole blood } \\
(0.25 \mathrm{~mL})\end{array}$ & $\begin{array}{l}\text { SPE (Oasis }{ }^{\circledR} \\
\text { MCX) }\end{array}$ & GC-MS & $40-5 \mu \mathrm{g} / \mathrm{L}$ & $40-5 \mu \mathrm{g} / \mathrm{L}$ & $70.3-116.6$ & [75] \\
\hline $\begin{array}{l}\text { Cathine, Cathinone, } \\
\text { Methcathinone and Ephedrine }\end{array}$ & $\begin{array}{l}\text { Oral fluid } \\
(0.5 \mathrm{~mL})\end{array}$ & $\begin{array}{c}\text { LLE } \\
\text { (ethyl acetate) }\end{array}$ & GC-MS (EI) & $10.0 \mu \mathrm{g} / \mathrm{L}$ & $20.0 \mu \mathrm{g} / \mathrm{L}$ & - & [73] \\
\hline
\end{tabular}

Caption: EI (electron impact); ESI (electrospray ionization); GC (gas chromatography); LC (liquid chromatography); LLE (liquid-liquid extraction); MS (mass spectrometry); MS/MS (tandem mass spectrometry); PP (protein precipitation); SPE (solid-phase extraction).

\section{Datura stramonium (Jimson Weed)}

D. stramonium (Figure 5A), originally from the United States of America, consists of a seasonal herb that grows naturally [2]. This species, also known as Jimson Weed, was traditionally used by the Pueblo Indians, due to its analgesic properties [76]. Moreover, in Western medicine, Jimson Weed was used to treat asthma [76]. This plant is usually consumed by eating its seeds or flowers intact, or in the form of an infusion of leaves or crushed seeds [77,78]. Dried leaves, flowers and seeds are also consumed in a smoked form, and there is also Asthmador ${ }^{\mathrm{TM}}$ powder available for consumption in smoked form or by inhalation $[78,79]$. The consumption of $D$. stramonium also causes hallucinogenic effects, which are due to the presence of the alkaloids scopolamine (Figure 5B) and atropine (Figure 5C) distributed throughout the plant [2]. These compounds are tertiary amines and therefore cross the blood-brain barrier rapidly [79]. Scopolamine acts at the level of the central nervous system, exerting antimuscarinic effects [80]. The effects of Jimson Weed consumption include tachypnea, delirium, psychomotor agitation, dilation of the pupils, blurred vision or photophobia $[78,79,81]$. Other effects, such as peripheral vasodilation, decreased thermoregulation, vomiting, constipation and difficulties in urinating, have been also described [76,82]. At higher doses, respiratory depression and even cardiac arrest, seizures or hypoventilation may occur [79]. Some analytical methods have been developed to quantify the alkaloids scopolamine and atropine (Table 4). These are discussed below. 


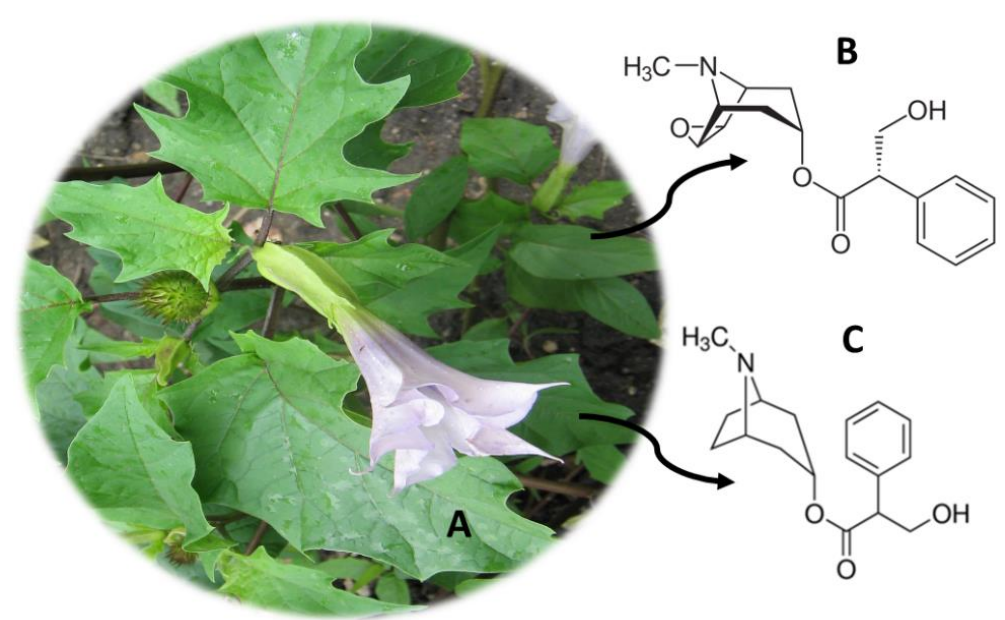

Figure 5. Datura stramonium (A) and the main compounds scopolamine (B) and atropine (C).

\section{Mandragora officinarum (Mandrake)}

M. officinarum (Figure 6A) is widely distributed worldwide, namely in Europe, North Africa, the Middle East and the Himalayas, however originating from the eastern Mediterranean [2]. This plant, also known as mandrake, has in the constitution of its seeds, roots, leaves and fruits, hyoscyamine (Figure 6B), atropine (Figure 6C) and scopolamine (Figure 6D), responsible for its healing, hallucinogenic and poisonous properties $[83,84]$. Since ancient times, mandrake was used as a surgical anesthetic in Rome and Greece [85]. It is also believed that this plant has aphrodisiac properties and its fruit increases fertility [85].

The consumption of mandrake can compromise the autonomic nervous system, resulting in an anticholinergic action and, consequently, reducing neuronal activity mediated by acetylcholine $[86,87]$. Thus, effects such as dry mouth, urinary retention, increased heart rate, mydriasis and decreased secretions are described [3,86,87]. In more extreme cases, its consumption can induce coma or even cause death [3]. Thus, the use of this plant is controlled both in the United States of America and in Europe, with the imposed measures being very restrictive [3].

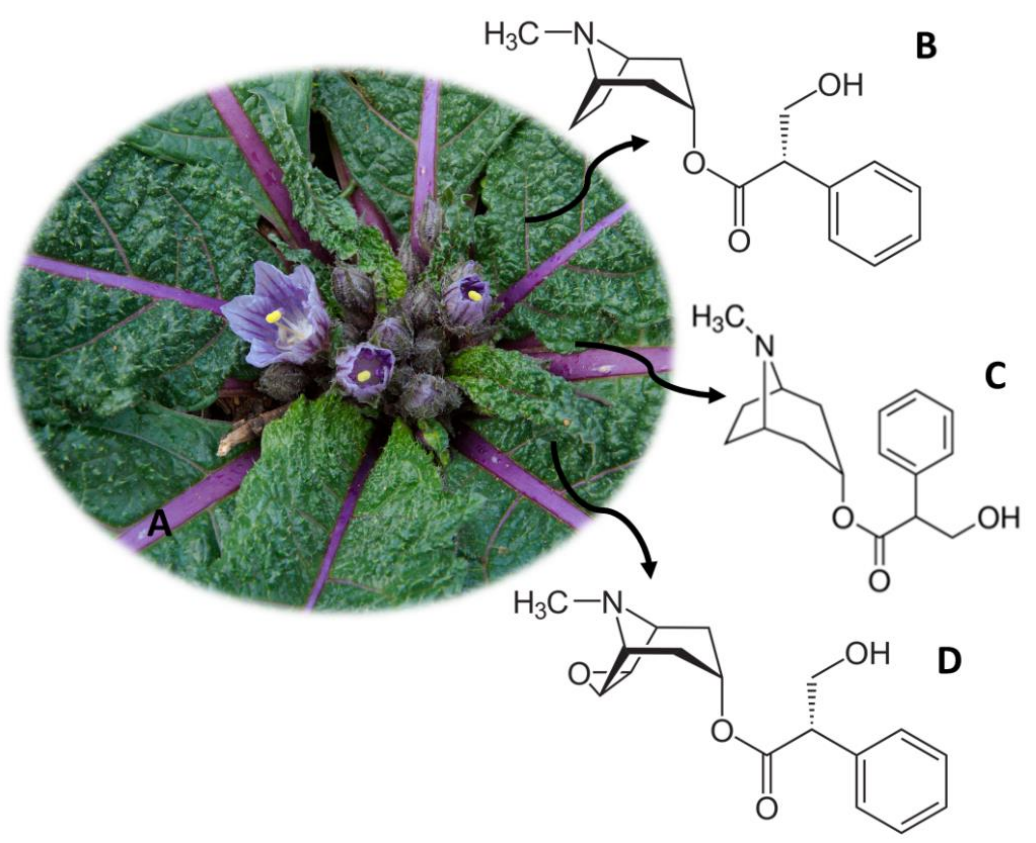

Figure 6. M. officinarum (A) and the main compounds hyoscyamine (B), atropine (C) and scopolamine (D). 
There are currently analytical methodologies developed with different biological samples, which allow the quantification of atropine and scopolamine (Table 4). Pietsch et al. [88] developed an analytical method with $1 \mathrm{~mL}$ of serum and urine to detect and quantify 13 compounds, namely scopolamine and atropine. The analytes were extracted using the SPE technique and quantified using HPLC-PDA and HPLC-UV equipment [88]. The method presented quantification limits of $0.3-94 \mathrm{ng} / \mathrm{mL}$ and recoveries between $23.7 \%$ and $86.9 \%$ [88]. In addition, Carlier et al. [89] quantified atropine and scopolamine, among other compounds, in a single analytical method. The SPE technique was used as a pre-treatment of the blood sample $(1 \mathrm{~mL})$, having subsequently been quantified in UHPLC-MS/MS equipment [89]. The method had a LOQ of $10 \mathrm{ng} / \mathrm{mL}$ and detection limits between 0.1 and $1.6 \mathrm{ng} / \mathrm{mL}$ [89].

Table 4. Analytical methods for the determination of the main components of Datura stramonium and Mandragora officinarum.

\begin{tabular}{|c|c|c|c|c|c|c|c|}
\hline Compounds & $\begin{array}{l}\text { Sample } \\
\text { (Amount) }\end{array}$ & $\begin{array}{c}\text { Sample } \\
\text { Preparation }\end{array}$ & $\begin{array}{l}\text { Analytical } \\
\text { Technique }\end{array}$ & $\begin{array}{l}\text { Limits of } \\
\text { Detection }\end{array}$ & $\begin{array}{c}\text { Limits of } \\
\text { Quantitation }\end{array}$ & $\begin{array}{c}\text { Recovery } \\
(\%)\end{array}$ & Reference \\
\hline $\begin{array}{l}\text { Hyoscyamine and } \\
\text { Scopolamine }\end{array}$ & $\begin{array}{c}\text { Serum }(0.5 \mathrm{~mL}) \\
\text { and Urine }(0.5 \\
\mathrm{mL})\end{array}$ & $\begin{array}{c}\text { SPE } \\
\text { (Extrelut1) }\end{array}$ & GC-MS (EI) & $5.0 \mu \mathrm{g} / \mathrm{L}$ & - & $>80$ & [90] \\
\hline $\begin{array}{c}\text { Atropine, DMT, Ephedrine, } \\
\text { Harmaline, Harmine, } \\
\text { Ibogaine, LSA, Psilocin, } \\
\text { Scopolamine and } \\
\text { Yohimbine }\end{array}$ & $\begin{array}{l}\text { Urine }(0.05 \\
\mathrm{mL})\end{array}$ & $\begin{array}{l}\text { Dilution } \\
\text { (distilled } \\
\text { water) }\end{array}$ & $\begin{array}{l}\text { LC-MS/MS } \\
\text { (ESI) }\end{array}$ & $\begin{array}{l}2.0-10.0 \\
\mu \mathrm{g} / \mathrm{L}\end{array}$ & - & - & [91] \\
\hline $\begin{array}{c}\alpha \text {-lobeline, } \alpha \text {-solanine, } \\
\text { Aconitine, Ajmaline, } \\
\text { Atropine, Brucine, } \\
\text { Cephalomannine, } \\
\text { Colchicine, Convallatoxin, } \\
\text { Cymarine, Cytisine, } \\
\text { Digitoxin, Digoxin, } \\
\text { Emetine, Gelsemine, } \\
\text { Ibogaine, Jervine, Kavain, } \\
\text { Lanatoside C, Lupanine, } \\
\text { Mitragynine, Neriifolin, } \\
\text { Oleandrin, Ouabain, } \\
\text { Paclitaxel, Physostigmine, } \\
\text { Pilocarpine, } \\
\text { Podophyllotoxin, } \\
\text { Proscillaridin A, Reserpine, } \\
\text { Retrorsine, Ricinine, } \\
\text { Scopolamine, Senecionine, } \\
\text { Sparteine, Strophanthidin, } \\
\text { Strychnine, Veratridine and } \\
\text { Yohimbine }\end{array}$ & Blood (1 mL) & $\begin{array}{l}\text { SPE (HLB } \\
\text { Oasis } 囚)\end{array}$ & $\begin{array}{l}\text { UHPLC- } \\
\text { MS/MS } \\
\text { (ESI) }\end{array}$ & $0.1-1.6 \mu \mathrm{g} / \mathrm{L}$ & $10 \mu \mathrm{g} / \mathrm{L}$ & 33-106 & [89] \\
\hline
\end{tabular}

Caption: EI (electron impact); ESI (electrospray ionization); GC (gas chromatography); LC (liquid chromatography); MS (mass spectrometry); MS/MS (tandem mass spectrometry); SPE (solid-phase extraction); UHPLC (ultrahigh-performance liquid chromatography).

\section{Lophophora williamsii (Peyote)}

L. williamsii (Figure 7A), also known as Peyote, is a cactus from northern Mexico and the United States of America [92,93]. This plant was traditionally eaten in religious rituals, by indigenous peoples in the countries already mentioned [50]. Normally, the flesh of the fresh cactus is ingested, and it can also be dried and subsequently ingested or used to make teas [92,94]. L. williamsii contains a compound called mescaline [2-(3,4,5-trimethylphenyl) ethanamine] (Figure 7B), a member of the phenylalkylamine class, responsible for the hallucinogenic properties of the plant $[79,95]$. This compound is also found for sale in the form of powder, which can be inflated or ingested orally [79]. Once consumed, mescaline accesses the central nervous system, acting at the level of serotonergic receptors 5-HT2 as an agonist of subtypes 5-HT2a, 5-HT2b and 5-HT2c [95].

The effects when consuming this plant include paranoia, compulsion, paresthesia, changes in color perception, headaches, mydriasis, spasms and psychomotor agitation $[93,96,97]$. Other effects at the cardiovascular, gastrointestinal and renal levels have been also described, namely hypertension and tachycardia, vomiting and decreased fil- 
tration rate at the glomerular level $[93,98,99]$. However, beneficial effects have been also described. One study demonstrated that L. williamsii extracts were effective in treating rheumatism, wounds, burns and snakebites [100]. Another study showed that this plant has antimicrobial properties against Staphylococcus aureus [100] Additionally, L. williamsii is used by some tribes to treat fever, labor pain, toothache, diabetes, blindness, breast pain and skin diseases [100].

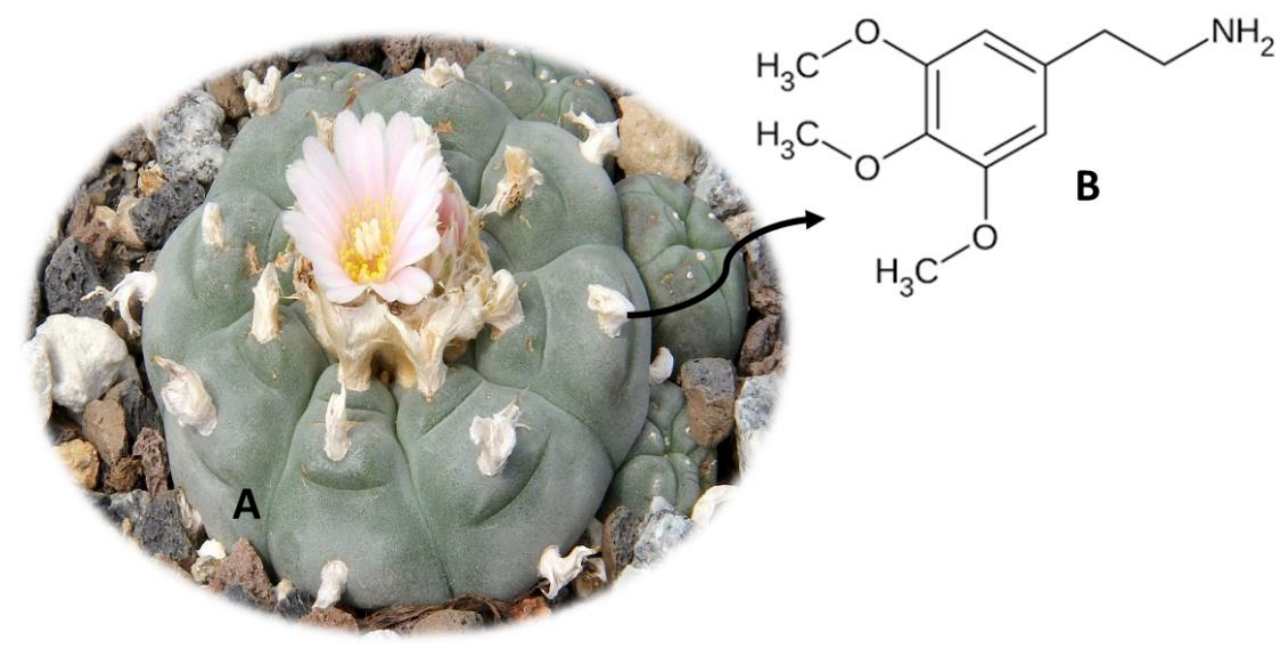

Figure 7. Lophophora williamsii (A) and the main compound mescaline (B).

Currently, substances containing mescaline are included in Annex I of the 1967 United Nations Convention on Drugs [100]. Given the effects of this plant, it is crucial to develop new analytical methodologies to detect mescaline and its metabolites in biological samples. Until now, methodologies have been developed using chromatography, namely in alternative samples such as hair [67]. Pichini et al. [67] developed an analytical method, using UHPLC-MS/MS equipment, to quantify several naturally occurring hallucinogens, including mescaline. For this purpose, $25 \mathrm{mg}$ of hair was hydrolyzed with an M3 reagent. The method presented LOD values between $0.01 \mathrm{ng} / \mathrm{mg}$ and $0.02 \mathrm{ng} / \mathrm{mg}$, LOQ between $0.03 \mathrm{ng} / \mathrm{mg}$ and $0.05 \mathrm{ng} / \mathrm{mg}$ and recoveries between $79.6 \%$ and $97.4 \%$ [67]. Another study by Beyer et al. [71] also allowed to quantify mescaline, using LC-MS/MS equipment with $1 \mathrm{~mL}$ of plasma, pre-treated with the SPE technique.

\section{Mitragyna speciosa (Kratom)}

M. speciosa (Figure 8A), also known as Kratom, appeared on the Asian continent, namely in countries like Biak, Malaysia and Thailand [2]. Currently, this plant is distributed in several regions of the world $[3,12]$. M. speciosa has been used for several years by rural workers and peasants in Asian people for reducing fatigue and increasing productivity at work, coughing, pain, fever, diarrhea, hypertension and diabetes. More recently, it began to be consumed in a recreational context in Europe and the United States of America [101-109]. Kratom leaves have been also used as a substitute for opium, as well as in morphine withdrawal treatments $[12,50]$. The preferred mode of consumption is chewing fresh leaves, but dried leaves can also be eaten or smoked [3,50]. Other forms of consumption of this plant include the preparation of teas and pastes by boiling the leaves for a long period [16]. Currently, there is greater ease in the consumption of this plant, since capsules, powders and drinks are available that can be easily purchased $[3,110]$. 


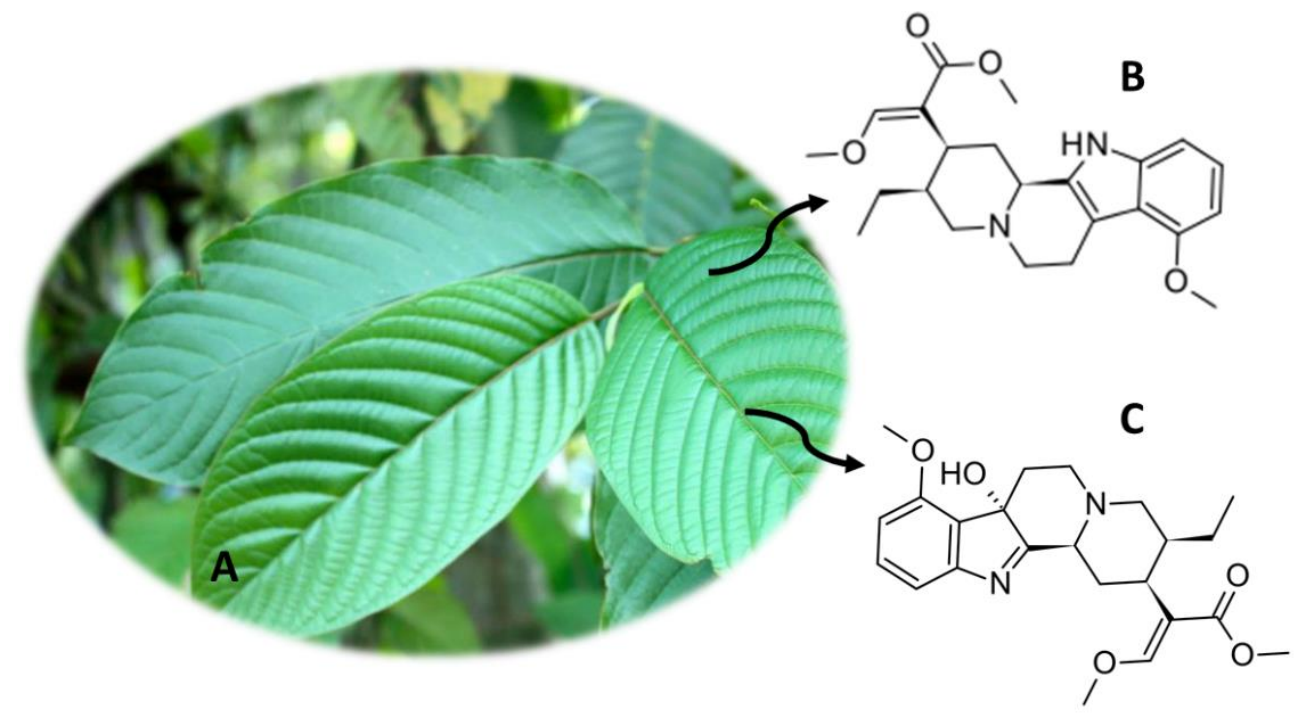

Figure 8. M. speciosa (A) and the main compounds mitragynine (B) and 7-hydroxymitragynine (C).

Kratom has psychoactive properties, which are due to the presence of about 40 alkaloids in the plant $[3,50]$. These compounds correspond to about $0.5 \%-1.5 \%$ of the compounds and their concentrations vary with the harvesting season, age and geographic location $[3,111]$. The most abundant psychoactive compound is mitragynine (Figure $8 \mathrm{~B}$ ), corresponding to a total of $66.2 \%$ of the alkaloids content. However, the abundance of this compound in Malaysian plants was only 10\% [12]. Other alkaloids with pharmacological activity were also detected, such as 7-hydroxmitraginine (Figure 8C) and corinantheidine [110-114]. In addition, other alkaloids have been discovered that may contribute to pharmacological effects, namely corinantheidine, specioginine and paynantheine [3]. The alkaloids present in M. speciosa show high lipophilicity, crossing the blood-brain barrier, and a high affinity for opioid receptors [3]. Thus, 7-hydroxmitraginin binds to the supraspinous k-opioid and $\mu$-opioid receptors, exerting their effects [3]. In addition to these, mitragynine binds to $\delta$-opioid receptors, thereby exercising analgesic effects $[3,50]$. Mitragynine is able to block $\mathrm{Ca}^{2+}$ channels, affecting the release of neurotransmitters $[115,116]$. Thus, antidepressant, antioxidant and anti-inflammatory properties have been associated with kratom consumption $[117,118]$. The use of this substance for substitution treatment in chronic opioid users has also been reported $[3,50]$.

Adverse effects when consuming this plant include withdrawal and neonatal withdrawal syndrome, seizures, weight loss, dehydration, fatigue, insomnia, constipation and hyperpigmentation $[50,103,105,119,120]$. However, M. speciosa is not on the United Nations Drug Convention Schedule [3]. These compounds are controlled in the United States of America, New Zealand, Australia, Myanmar, Thailand, Malaysia and in some European countries [3].

Thus, it is crucial to develop analytical methods to detect and quantify the compounds present in M. speciosa (Table 5). Carlier et al. [89] developed an analytical method where they used $1 \mathrm{~mL}$ of blood to detect mitragynine (among other compounds), using UHPLC-MS/MS equipment. Lee et al. [121] developed an analytical method in LCMS/MS, where they used SPE and enzymatic hydrolysis as a method of pre-treatment of the urine sample, to quantify 16-carboxy mitragynine, 9-O-demethyl mitragynine and mitragynine. More recently, Basiliere et al. [122] developed an analytical method using LC-Q/TOF-MS equipment for the quantification of mitragynine, 7-hydroxymitragynine, among other compounds. One milliliter of urine, pre-treated with SPE, was used, obtaining a LOD of $0.25-1 \mathrm{ng} / \mathrm{mL}$ and a LOQ of $0.5-1 \mathrm{ng} / \mathrm{mL}$ [122]. 
Table 5. Analytical methods for the determination of the main components of Mitragyna speciosa.

\begin{tabular}{|c|c|c|c|c|c|c|c|}
\hline Compounds & $\begin{array}{c}\text { Sample } \\
\text { (Amount) }\end{array}$ & Sample Preparation & $\begin{array}{l}\text { Analytical } \\
\text { Technique }\end{array}$ & $\begin{array}{l}\text { Limits of } \\
\text { Detection }\end{array}$ & $\begin{array}{l}\text { Limits of } \\
\text { Quantitation }\end{array}$ & Recovery (\%) & Reference \\
\hline $\begin{array}{c}\text { Mitragynine, } \\
\text { 7-hydroxymitragynine, } \\
\text { Speciociliatine, Speciogynine } \\
\text { and Paynantheine }\end{array}$ & Urine (1 mL) & $\begin{array}{c}\text { SPE (PolyChrom } \\
\text { ClinII } 3 \mathrm{~cm}^{3}(35 \mathrm{mg}) \text { ) }\end{array}$ & $\begin{array}{l}\text { LC-Q/TOF- } \\
\text { MS }\end{array}$ & $0.25-1 \mu \mathrm{g} / \mathrm{L}$ & $0.5-1 \mu \mathrm{g} / \mathrm{L}$ & - & [122] \\
\hline $\begin{array}{c}\text { Mitragynine, } \\
\text { 7-hydroxy-mitragynine, } \\
\text { 5-desmethyl-mitragynine, } \\
\text { 17- } \\
\text { desmethyldihydromitragynine } \\
\text { and mitraphylline }\end{array}$ & Urine $(0.2 \mathrm{~mL})$ & $\begin{array}{c}\text { Hydrolysis } \\
\text { ( } \beta \text {-Glucuronidase) } \\
\text { and LLE (methyl } \\
\text { tert-butyl ether) }\end{array}$ & $\underset{(\mathrm{ESI})}{\mathrm{LC}-\mathrm{MS} / \mathrm{MS}}$ & - & $1 \mu \mathrm{g} / \mathrm{L}$ & - & [123] \\
\hline $\begin{array}{l}\text { Mitragynine, 16-carboxy } \\
\text { mitragynine and } \\
\text { 9-O-demethyl mitragynine }\end{array}$ & Urine (1 mL) & $\begin{array}{c}\text { Hydrolysis } \\
\text { ( } \beta \text {-glucuronidase/ } \\
\text { arylsulfatase) and } \\
\text { SPE (Bond Elut } \\
\text { Certify } \\
\text { (200 mg, } 3 \mathrm{~mL} \text { ) and } \\
\text { Abs Elut-Nexus SPE } \\
(60 \mathrm{mg}, 3 \mathrm{~mL}))\end{array}$ & $\underset{\text { (ESI) }}{\text { LC-MS/MS }}$ & - & $1-50 \mu \mathrm{g} / \mathrm{L}$ & - & [121] \\
\hline $\begin{array}{c}\text { Mitragynine and } \\
\text { 7-hydroxymitragynine }\end{array}$ & Urine (1 mL) & $\begin{array}{l}\text { Dilution (water with } \\
0.1 \% \text { formic acid) }\end{array}$ & $\underset{(\mathrm{ESI})}{\mathrm{LC}-\mathrm{MS} / \mathrm{MS}}$ & $\begin{array}{c}0.012-0.069 \\
\mu \mathrm{g} / \mathrm{L}\end{array}$ & $\begin{array}{c}0.0356-0.215 \\
\mu \mathrm{g} / \mathrm{L}\end{array}$ & - & [124] \\
\hline
\end{tabular}

Caption: ESI (electrospray ionization); LC (liquid chromatography); LLE (liquid-liquid extraction); MS (mass spectrometry); MS/MS (tandem mass spectrometry); SPE (solid-phase extraction); Q/ToF (time of flight).

\section{Piper methysticum Forst (Kava)}

Some parts of P. methtysticum (Figure 9A) (roots and stems) are used in the manufacture of Kava, a psychotropic drink from the Pacific region [2]. Kava was consumed due to its therapeutic properties, namely in reducing fatigue and anxiety, relieving pain or inducing sleep [125]. Other treatments such as restlessness and anxiety were also associated with the consumption of Kava [3]. However, the use of this substance is associated with hepatotoxicity [125]. The effects of Kava are due to kavalactones, namely kavain (Figure 9B), yangonin (Figure 9C), desmethoxy-iangonin, 7,8-dihydrokavain, methysticin and 7,8dihydromethysticin, to the derivatives of cinnamic acid, flavanones and chalcones [2]. These compounds act at the level of the central nervous system, inhibiting monoamine oxidase $B$, recapturing of noradrenaline and dopamine and interacting with $\gamma$-amino butyric acid [126].

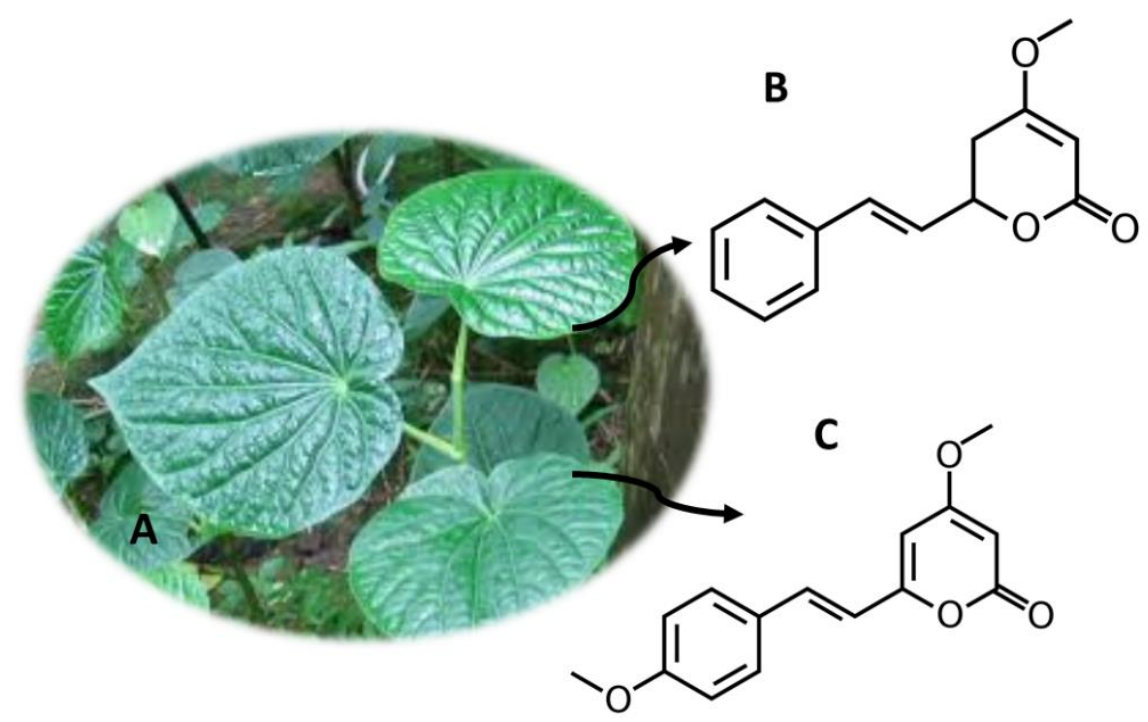

Figure 9. P. methysticum (A) and the main compounds kavain (B) and yangonin (C).

The sale of P. methysticum is controlled in Holland, Switzerland and France, and its sale and import are prohibited in the United Kingdom. In Poland, sales for human consumption are also prohibited. However, in most countries, this substance remains legal [3]. 
Thus, the development of analytical methods for the detection of these compounds is becoming increasingly important (Table 6). Villain et al. [127] developed a method for the determination of kavain in GC-MS/MS, using between 29 and $50 \mathrm{mg}$ of hair. The method had a LOD of $30 \mathrm{ng} / \mathrm{g}$ and a LOQ of $100 \mathrm{ng} / \mathrm{g}$ [127]. Another more recent study, carried out by Tarbah et al. [128], allowed to quantify 10 compounds, using between 21 and $253 \mathrm{mg}$ of hair. The sample was initially decontaminated, then digested, using three different types of equipment for quantification: HPLC-DAD, LC-MS/MS and GC/TOF-MS [128].

Table 6. Analytical methods for the determination of the main components of Piper methysticum.

\begin{tabular}{|c|c|c|c|c|c|c|c|}
\hline Compounds & $\begin{array}{c}\text { Sample } \\
\text { (Amount) }\end{array}$ & $\begin{array}{c}\text { Sample } \\
\text { Preparation }\end{array}$ & $\begin{array}{l}\text { Analytical } \\
\text { Technique }\end{array}$ & $\begin{array}{l}\text { Limits of } \\
\text { Detection }\end{array}$ & $\begin{array}{c}\text { Limits of } \\
\text { Quantitation }\end{array}$ & $\begin{array}{c}\text { Recovery } \\
(\%)\end{array}$ & Reference \\
\hline $\begin{array}{c}\text { Kavain, Dihydrokavain, } \\
\text { Methysticin, } \\
\text { Dihydromethysticin } \\
\text { and } \\
\text { Desmethoxyyangonin }\end{array}$ & $\begin{array}{l}\text { Urine }(0.1 \mathrm{~mL}) \\
\text { and Plasma } \\
(0.1 \mathrm{~mL})\end{array}$ & $\begin{array}{l}\text { PP (Methanol), } \\
\text { LLE (ethyl acetate) } \\
\text { and SPE (SOLA } \\
\text { HRP cartridge) }\end{array}$ & $\begin{array}{l}\text { UHPLC- } \\
\text { MS/MS } \\
\text { (HESI) }\end{array}$ & $\begin{array}{c}0.015-0.137 \\
\mu \mathrm{g} / \mathrm{L}\end{array}$ & $\begin{array}{c}0.0457-0.4165 \\
\mu \mathrm{g} / \mathrm{L}\end{array}$ & - & [129] \\
\hline Kavain & $\begin{array}{l}\text { Hair (29-50 } \\
\text { mg) }\end{array}$ & $\begin{array}{l}\text { Decontamination } \\
\text { (methylene } \\
\text { chloride) and } \\
\text { digestion } \\
\text { (methanol) }\end{array}$ & $\begin{array}{c}\text { GC-MS/MS } \\
(\mathrm{EI})\end{array}$ & $0.030 \mu \mathrm{g} / \mathrm{g}$ & $0.1 \mu \mathrm{g} / \mathrm{g}$ & - & [127] \\
\hline $\begin{array}{c}\text { Kavain, } p \text {-hydroxykavain, } \\
p \text {-hydroxy-5,6- } \\
\text { dehydrokavain and } \\
p \text {-hydroxy-7,8- } \\
\text { dihydrokavain }\end{array}$ & $\begin{array}{l}\text { Blood }(1 \mathrm{~mL}), \\
\text { Urine }(1 \mathrm{~mL}) \\
\text { and Serum } \\
(1 \mathrm{~mL})\end{array}$ & $\begin{array}{c}\text { LLE } \\
\text { (dichlormethane: } \\
\text { diethylether (7:3, } \\
v / v) \text { ) }\end{array}$ & $\begin{array}{l}\text { HPLC-DAD } \\
\text { and LC-MS }\end{array}$ & $1 \mu \mathrm{g} / \mathrm{L}$ & $5 \mu \mathrm{g} / \mathrm{L}$ & $91-97$ & {$[130]$} \\
\hline $\begin{array}{c}\text { Kavain, } \\
\text { 7,8-dihydrokavain, } \\
\text { Yangonin, } \\
\text { 5,6-dehydrokavain, } \\
\text { 12-hydroxy-5,6- } \\
\text { dehydrokavain, } \\
\text { Methysticin, } \\
\text { 7,8-dihydromethysticin, } \\
\text { 11-hydroxy-5,6- } \\
\text { dehydrokavain, } \\
\text { 12-hydroxykavain and } \\
\text { 12-hydroxy-7,8- } \\
\text { dihydrokavain }\end{array}$ & $\begin{array}{c}\text { Hair (21-253 } \\
\text { mg) }\end{array}$ & $\begin{array}{l}\text { Decontamination } \\
\text { (HPLC water, } \\
\text { acetone and } \\
\text { petroleumbenzene) } \\
\text { and digestion } \\
\text { (methanol) }\end{array}$ & $\begin{array}{l}\text { HPLC-DAD, } \\
\text { LC-MS/MS } \\
\text { (ESI) e } \\
\text { GC/TOF- } \\
\text { MS }\end{array}$ & - & - & - & [128] \\
\hline
\end{tabular}

Caption: DAD (diode array detector); EI (electron impact); ESI (electrospray ionization); GC (gas chromatography); HESI (heated electrospray); HPLC (high performance liquid chromatography); LC (liquid chromatography); LLE (liquid-liquid extraction); MS (mass spectrometry); MS/MS (tandem mass spectrometry); PP (protein precipitation); SPE (solid-phase extraction); ToF (time of flight); UHPLC (ultrahigh-performance liquid chromatography).

\section{Psilocybe Genus (Magic Mushrooms)}

Psilocybe (Figure 10A) is a genus of hallucinogenic fungi, commonly known as magic mushrooms [131]. These specimens originate from certain regions of South America, but it is also possible to find them in Western Europe and in the United States of America [79,92]. The magic mushrooms were initially used in religious rituals, by the Aztec people in Mexico, persisting until today $[50,79]$. The active compounds present in these fungi are psilocybin (Figure 10B) and psilocin (Figure 10C), which consist of a substituted indolealkylamine $[3,79]$. There are about 190 species of mushrooms of the genus Psilocybe, which contain these two compounds responsible for the psychoactive effects of these fungi [131]. Mushrooms can be eaten after drying and making tea, but the most common route of consumption is by eating whole mushroom capsules [92]. After being consumed, psilocybin is converted into psilocin, and it acts as an agonist for the serotonergic receptors 5-HT1a and 5-HT2a, exerting its psychoactive effects [79]. In addition, these compounds can also increase the release of glutamate, which activates receptors such as $N$-methyl-d-aspartic acid receptors and $\alpha$-amino-3-hydroxy-5-methyl-4-isoxazolepropionic acid receptors [50,132]. The effects caused when consuming magic mushrooms can also be partially and indirectly mediated by dopamine [133]. 


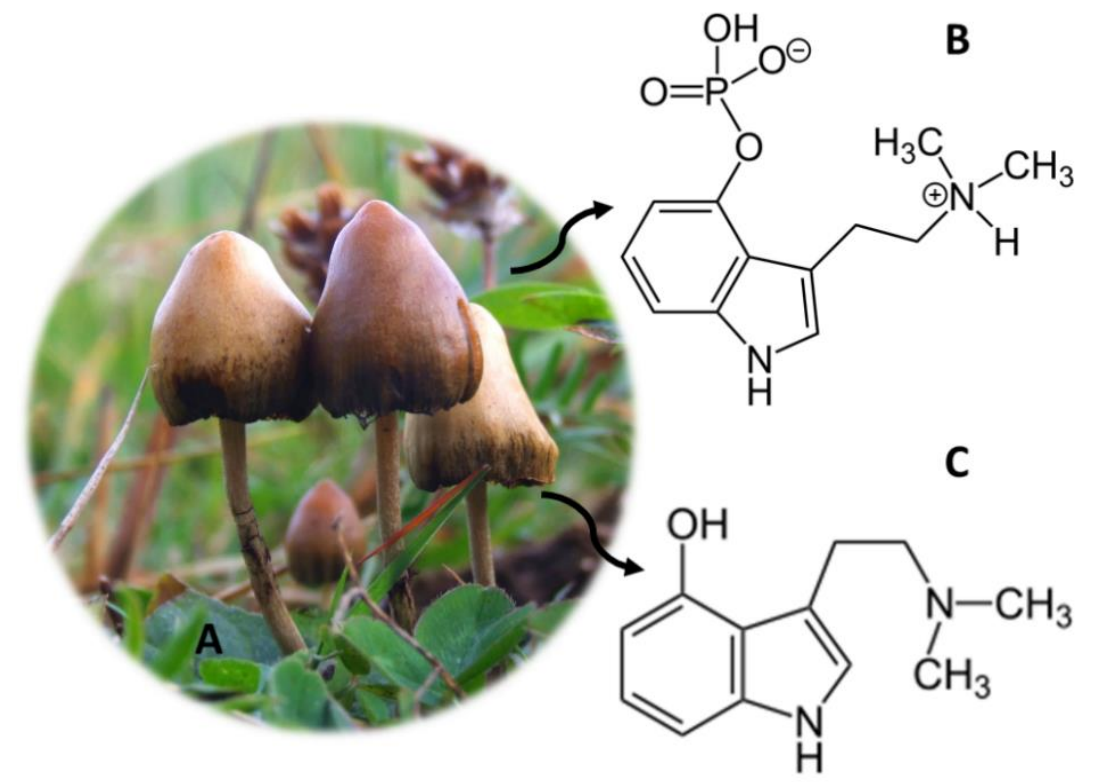

Figure 10. Psilocybe mushrooms (A) and the main compounds psilocybin (B) and psilocin (C).

The effects of Psilocybe consumption include changes in perception similar to drugs such as LSD, namely changes in visual and auditory perception [3]. Mystical experiences, tachycardia, headache, sweating, mydriasis, chills, nausea and increased body temperature are also associated with the consumption of magic mushrooms $[134,135]$. Other effects reported when consuming these substances are paranoia, dizziness and imbalance and abdominal pain, $[79,135]$. Moreover, it has been reported that psilocybin can be used to treat anxiety and resistant depression [136].

Psilocybe mushrooms are illegal all over the world [137]. However, in some countries, the law is not consensual, namely in the Netherlands where the mushroom is illegal, but the Sclerotia truffle (philosopher's stone) is not [3]. Given the worldwide consumption of this substance, the development of new analytical methods that allow the determination of these compounds is crucial (Table 7). Several samples were used to quantify the active compounds of Psilocybe, namely urine [91,138], serum [139] and hair [67]. Kamata et al. [139] developed a method for the quantification of psilocin glucuronide, where they used only $100 \mu \mathrm{L}$ of serum. The sample was subjected to an enzymatic hydrolysis and deproteinization process, after which it was injected into LC-MS and LC-MS/MS equipment. The method showed $0.5 \mathrm{ng} / \mathrm{mL}$ LOD. The same authors had previously developed an analytical method for the quantification of psilocin glucuronide and psilocin, where they used the same volume of urine and the same equipment, and the same LOD was obtained [138]. 
Table 7. Analytical methods for the determination of the main components of the Psilocybe genus.

\begin{tabular}{|c|c|c|c|c|c|c|c|}
\hline Compounds & $\begin{array}{c}\text { Sample } \\
\text { (Amount) }\end{array}$ & Sample Preparation & $\begin{array}{l}\text { Analytical } \\
\text { Technique }\end{array}$ & $\begin{array}{l}\text { Limits of } \\
\text { Detection }\end{array}$ & $\begin{array}{c}\text { Limits of } \\
\text { Quantitation }\end{array}$ & $\begin{array}{c}\text { Recovery } \\
(\%)\end{array}$ & Reference \\
\hline $\begin{array}{l}\text { Psilocin } \\
\text { glucuronide } \\
\text { and Psilocin }\end{array}$ & Urine $(0.1 \mathrm{~mL})$ & $\begin{array}{c}\text { Enzymatic } \\
\text { hydrolyses } \\
\text { ( } \beta \text {-glucuronidase), } \\
\text { alkaline hydrolyses } \\
\text { (potassium } \\
\text { hydroxide) acid } \\
\text { hydrolysis (concen- } \\
\text { tratedhydrochloric } \\
\text { acid) and } \\
\text { deproteinization } \\
\text { (methanol) }\end{array}$ & $\begin{array}{l}\text { LC-MS (ESI) } \\
\text { and } \\
\text { LC-MS/MS } \\
\text { (ESI) }\end{array}$ & $0.5 \mu \mathrm{g} / \mathrm{L}$ & - & - & [138] \\
\hline $\begin{array}{l}\text { Psilocin } \\
\text { glucuronide }\end{array}$ & Serum $(0.1 \mathrm{~mL})$ & $\begin{array}{c}\text { Enzymatic hydrolysis } \\
\text { ( } \beta \text {-glucuronidase) } \\
\text { and deproteinization } \\
\text { (methanol) }\end{array}$ & $\begin{array}{l}\text { LC-MS (ESI) } \\
\text { and } \\
\text { LC-MS/MS } \\
\text { (ESI) }\end{array}$ & $0.5 \mu \mathrm{g} / \mathrm{L}$ & - & - & [139] \\
\hline $\begin{array}{l}\text { Mescaline, } \\
\text { DMT, Psilocin, } \\
\text { Psilocybin and } \\
\text { Salvinorin A }\end{array}$ & Hair (25 mg) & $\begin{array}{l}\text { Hydrolysis } \\
\text { (M3reagent) }\end{array}$ & $\begin{array}{l}\text { UHPLC- } \\
\text { MS/MS } \\
\text { (ESI) }\end{array}$ & $0.01-0.02 \mu \mathrm{g} / \mathrm{g}$ & $0.03-0.05 \mu \mathrm{g} / \mathrm{g}$ & $79.6-97.4$ & [67] \\
\hline
\end{tabular}

Caption: ESI (electrospray ionization); LC (liquid chromatography); MS (mass spectrometry); MS/MS (tandem mass spectrometry); UHPLC (ultrahigh-performance liquid chromatography).

\section{Salvia divinorum ("Hierba de Maria")}

S. divinorum (Figure 11A) originates from Oaxaca, a region in the northeast of the Sierra Mazateca, Mexico [140]. This psychoactive plant, also known as hierba de Maria, hojas de la Pastora, ska Maria, ska Pastora and magic mint, has been used for centuries by indigenous people because they believe it is the reincarnation of the Virgin Mary [12,141]. S. divinorum is consumed by chewing fresh or dried leaves. Dried leaves can be also smoked, and fresh leaves can be used to make tea [3]. The main psychoactive constituent of this plant is salvinorin A (Figure 11B), but other compounds were also detected, such as salvinorins B (Figure 11C), C, D, E and F, but these do not have pharmacological activity [3,12]. Salvinorin A acts as a selective agonist for Kappa opioid receptors (KOR), thereby exerting its potent hallucinogenic effects [12,142]. A dose of between $200 \mu \mathrm{g}$ and $500 \mu \mathrm{g}$ is capable of inducing deep hallucinations with extraordinary illusions and a feeling of physical and mental displacement $[143,144]$. However, some studies conducted with S. divinorum and its bioactive compound salvinorin A have shown that it has some effects with therapeutic potential, such as drug addiction, pain treatment, neurological, gastrointestinal diseases and anti-inflammatory agent [145-156].

Despite its high potency, this substance is not included in any of the United Nations Drug Conventions' Schedules [3]. However, in Denmark, Latvia, Belgium, Lithuania, Sweden, Romania, Japan and Australia, these compounds are controlled. S. divinorum is considered an illegal drug in the United States of America, and its sale in Canada is also prohibited [3]. Other countries such as Germany, Poland, Croatia and Spain regulate its manufacture, and in Norway, Estonia and Finland this plant is legislated by the legislation of medicines [3]. Together with the consumption of C. edulis and M. speciosa, the consumption of S. divinorum is controlled by the United Nations Office on Drugs and Crime (UNODC) [3].

The consumption of this substance has expanded worldwide and, therefore, several analytical methodologies for the detection of salvinorin A have emerged (Table 8). Thus, several biological samples have been used for the development of these analytical methodologies, namely, urine [157-160], plasma [159,161], saliva [161], sweat [161], pericardial fluid [161], vitreous humor [161], blood [161] and hair [67]. Margalho et al. [161] quantified salvinorin A in pericardial fluid, vitreous humor, blood and plasma in the same analytical method. The quantity of the samples was reduced $(100 \mu \mathrm{L}-250 \mu \mathrm{L})$, being treated using the SPE technique [161]. Finally, the compounds were quantified using GC-MS equipment, and the method proved to be sensitive and selective, presenting LOD and LOQ 
of $5 \mathrm{ng} / \mathrm{mg}$ [161]. Moreno et al. [160] quantified salvinorin A in urine samples (200 $\mu \mathrm{L})$ using MEPS as the sample pre-treatment technique. The samples were analyzed by GCMS/MS equipment, with good recoveries (71\%-80\%) and good LOD and LOQ (5 ng/mL and $20 \mathrm{ng} / \mathrm{mL}$, respectively) [160].

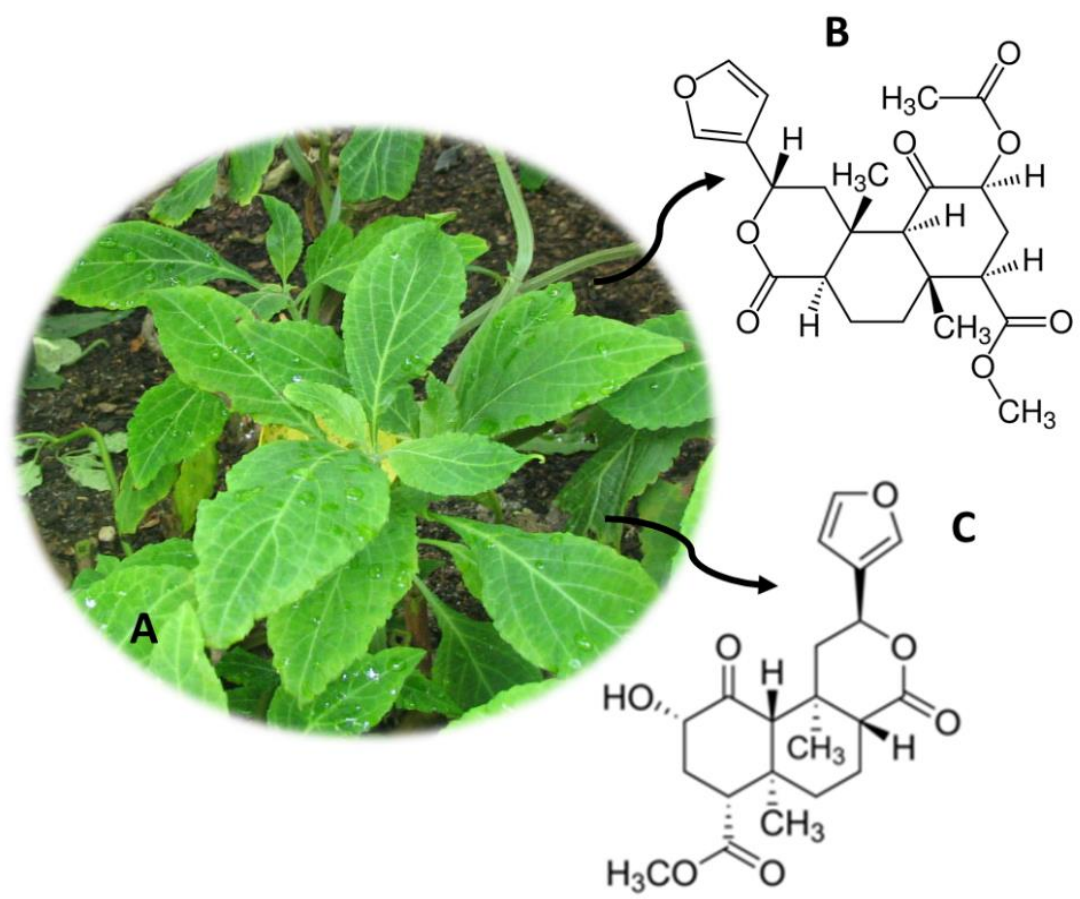

Figure 11. S. divinorum (A) and the main compounds salvinorin A (B) and salvinorin B (C).

Table 8. Analytical methods for the determination of the main components of Salvia divinorum.

\begin{tabular}{|c|c|c|c|c|c|c|c|}
\hline Compounds & Sample (Amount) & $\begin{array}{c}\text { Sample } \\
\text { Preparation }\end{array}$ & $\begin{array}{l}\text { Analytical } \\
\text { Technique }\end{array}$ & $\begin{array}{l}\text { Limits of } \\
\text { Detection }\end{array}$ & $\begin{array}{c}\text { Limits of } \\
\text { Quantitation }\end{array}$ & $\begin{array}{c}\text { Recovery } \\
(\%)\end{array}$ & Reference \\
\hline Salvinorin A & Urine $(20 \mathrm{~mL})$ & $\begin{array}{l}\text { LLE (chloroform) } \\
\text { and SPME } \\
\text { (85 } \mu \text { m polyacry- } \\
\text { late fiber) }\end{array}$ & $\begin{array}{c}\text { GC } \times \text { GC }- \\
\text { ToF-MS }\end{array}$ & $4-200 \mu \mathrm{g} / \mathrm{L}$ & - & - & [157] \\
\hline Salvinorin A & Urine (1 mL) & $\begin{array}{l}\text { SPE (Waters } \\
\text { Oasis }{ }^{\circledR} \mathrm{HLB} \text { ) }\end{array}$ & LC-MS (ESI) & $5 \mu \mathrm{g} / \mathrm{L}$ & $2.5 \mu \mathrm{g} / \mathrm{L}$ & - & [158] \\
\hline Salvinorin A & $\begin{array}{c}\text { Plasma }(1 \mathrm{~mL}), \\
\text { Urine }(1 \mathrm{~mL}), \\
\text { Saliva }(1 \mathrm{~mL}) \text { and } \\
\text { Sweat }(1 \text { patch cut } \\
\text { into littlepieces) }\end{array}$ & $\begin{array}{c}\text { LLE (chloro- } \\
\text { form/isopropanol } \\
(9: 1 \\
v / v)\end{array}$ & GC-MS (EI) & $3-5 \mu \mathrm{g} / \mathrm{L}$ & $10-15 \mu \mathrm{g} / \mathrm{L}$ & $77.1-92.7$ & [159] \\
\hline Salvinorin A & $\begin{array}{c}\text { Pericardial fluid } \\
(0.25 \mathrm{~mL}), \text { Vitreous } \\
\text { humor }(0.1 \mathrm{~mL}), \\
\text { Blood }(0.25 \mathrm{~mL}) \\
\text { and Plasma } \\
(0.25 \mathrm{~mL})\end{array}$ & $\begin{array}{l}\text { SPE (Waters } \\
\text { Oasis }{ }^{\circledR} \text { HLB) }\end{array}$ & GC-MS (EI) & $5.0 \mu \mathrm{g} / \mathrm{L}$ & $5.0 \mu \mathrm{g} / \mathrm{L}$ & - & [161] \\
\hline Salvinorin A & Urine $(0.2 \mathrm{~mL})$ & $\operatorname{MEPS}\left(\mathrm{C}_{18}\right)$ & $\underset{(\mathrm{EI})}{\mathrm{GC}-\mathrm{MS} / \mathrm{MS}}$ & $5.0 \mu \mathrm{g} / \mathrm{L}$ & $20 \mu \mathrm{g} / \mathrm{L}$ & $71-80$ & [160] \\
\hline
\end{tabular}

Caption: EI (electron impact); ESI (electrospray ionization); GC (gas chromatography); GC $\times$ GC (bidimensional gas chromatography); LC (liquid chromatography); LLE (liquid-liquid extraction); MEPS (microextraction by packed sorbent); MS (mass spectrometry); MS/MS (tandem mass spectrometry); SPE (solid-phase extraction); ToF (time of flight).

\section{Tabernanthe iboga (Iboga)}

T. iboga (Figure 12A) is a shrub from Central and West Africa [94,162]. This plant has been consumed for centuries in religious rituals of initiation into adulthood (Bwiti religion) in countries located in Central Africa and in the Congo basin [94,163]. The root 
barks of T. iboga contain psychoactive alkaloids, the majority of which are called ibogaine (Figure 12B) [162]. This compound, which consists of a monoterpene-indole alkaloid, is consumed orally in the form of hydrochloride, extracts of alkaloids or by consumption of the dry root bark $[162,164,165]$. When consuming, users experience stimulating and aphrodisiac properties, trance, energization and increased alertness [94,163]. The consumption of this substance also causes hallucinations that, in contrast to common hallucinogens, are more intense and realistic when experienced with closed eyes [162]. Despite the structure of ibogaine being similar to other hallucinogens, this compound has a different mode of action [162]. So far, its mechanism of action is not fully known, but it is known that it is able to act as an agonist of $\sigma 2$ receptors and an antagonist of nicotinic $\alpha 3 \beta 4$ acetylcholine receptors and as an antagonist at N-methyl-d-aspartatetype (NMDA) glutamate receptors $[164,165]$.

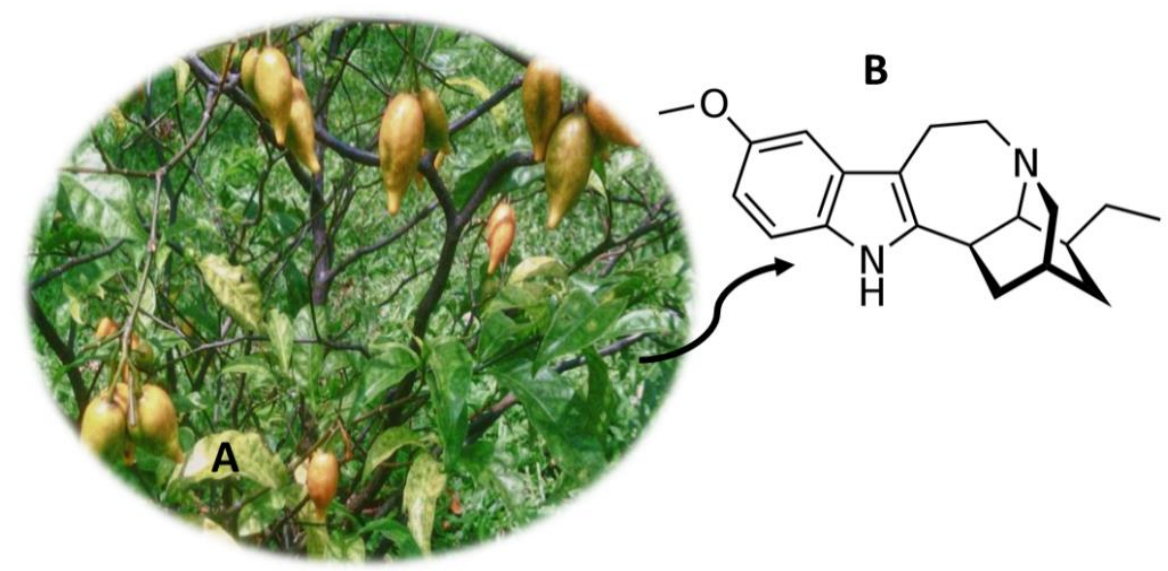

Figure 12. Tabernanthe iboga (A) and the main compound ibogaine (B).

Throughout history, the extract of $T$. iboga has been used for other purposes, namely for fatigue and depression [166]. Currently, ibogaine is used in opioid detoxification [94,162]. Thus, this compound is legal in most countries, however, in Switzerland, Belgium, Australia, Sweden, France, Denmark and the United States of America, it is illegal [162]. Currently, there are several methodologies for quantifying T. iboga compounds, namely using biological samples such as plasma [167], urine [88,91], blood [89] and serum [88]. Pietsch et al. [88] developed an analytical method where they determined, among other compounds, ibogaine. For this, they used HPLC-PDA and HPLC-UV equipment, using $1 \mathrm{~mL}$ of serum and $1 \mathrm{~mL}$ of urine, which were pre-treated with SPE [88]. Furthermore, Björnstad et al. [91] developed an analytical method where they quantified ibogaine and other compounds. This analytical method had a LOD between $2 \mathrm{ng} / \mathrm{mL}$ and $10 \mathrm{ng} / \mathrm{mL}$ and presented a very easy sample preparation technique [91]. Only $50 \mu \mathrm{L}$ of urine were used, which were diluted and injected directly into LC-MS/MS equipment [91].

\section{Conclusions}

Throughout this review, several plants/fungi that have psychoactive substances capable of inducing relaxing, stimulating or hallucinogenic effects were addressed. Toxicological aspects, some therapeutic properties and traditional uses were highlighted, as well as some of the analytical methods, developed in biological matrices, aimed at the detection of these substances.

Given the rapid emergence of these psychoactive substances in the abused drugs market, as well as the lack of legislation to control them, the development of new analytical methodologies is crucial. However, the lack of analytical standards to proceed with the development of chromatographic methods or the difficulty in finding plant specimens that allow scans of the compounds present in them constitute an enormous difficulty. Additionally, the fact that the compounds are usually present in very small amounts makes 
it even more difficult to develop and validate new methodologies, requiring the use of more sophisticated equipment, such as mass spectrometry detectors. Finally, the fact that the matrices of plant origin have several interferents also constitutes a difficulty, since it is necessary to apply a pre-treatment step to the sample. This procedure makes the development of methods more expensive and requires the use of organic solvents. In the future, the use of miniaturized extraction techniques should be prioritized in order to achieve the development of more economical methods that aim to use lower volumes of organic solvents and, consequently, be more environment-friendly.

Author Contributions: Conceptualization, Â.L., E.G. and A.P.D.; formal analysis, A.P.D. and E.G.; research and writing—original draft preparation, J.G.; writing—review and editing, J.G., Â.L., E.G. and A.P.D. All authors have read and agreed to the published version of the manuscript.

Funding: This work was partially supported by CICS-UBI, which is financed by National Funds from Fundação para a Ciência e a Tecnologia (FCT) and by Fundo Europeu de Desenvolvimento Regional (FEDER) under the scope of PORTUGAL 2020 and Programa Operacional do Centro (CENTRO 2020), with the project reference UIDB/00709/2020. Joana Gonçalves acknowledges the Ph.D. fellowship from FCT (Reference: SFRH/BD/149360/2019). Ângelo Luís acknowledges the contract of Scientific Employment in the scientific area of Microbiology financed by FCT.

Institutional Review Board Statement: Not applicable.

Informed Consent Statement: Not applicable.

Conflicts of Interest: The authors declare no conflict of interest.

\section{References}

1. European Monitoring Centre for Drugs and Drug Addiction. EU Drug Markets Report 2019; Publications Office of the European Union: Luxembourg, 2019; pp. 1-260. [CrossRef]

2. Simão, A.Y.; Antunes, M.; Marques, H.; Rosado, T.; Soares, S.; Gonçalves, J.; Barroso, M.; Andraus, M.; Gallardo, E. Recent bionalytical methods for the determination of new psychoactive substances in biological specimens. Bioanalysis 2020, 12, 1557-1595. [CrossRef]

3. Lo Faro, A.F.; Di Trana, A.; La Maida, N.; Tagliabracci, A.; Giorgetti, R.; Busardò, F.P. Biomedical analysis of New Psychoactive Substances (NPS) of natural origin. J. Pharm. Biomed. Anal. 2020, 179, 112945. [CrossRef]

4. Guirguis, A. New psychoactive substances: A public health issue. Int. J. Pharm. Practice 2017, 25, 323-325. [CrossRef] [PubMed]

5. Salomone, A.; Palamar, J.J.; Gerace, E.; Di Corcia, D.; Vincenti, M. Hair testing for drugs of abuse and new psychoactive substances in a high-risk population. J. Anal. Toxicol. 2017, 41, 376-381. [CrossRef] [PubMed]

6. Archer, J.R.H.; Mendes, F.; Hudson, S.; Layne, K.; Dargan, P.I.; Wood, D.M. Evaluation of long-term detection trends of new psychoactive substances in pooled urine from city street portable urinals (London, UK). Br. J. Clin. Pharmacol. 2020, 86, 517-527. [CrossRef] [PubMed]

7. Peacock, A.; Bruno, R.; Gisev, N.; Degenhardt, L.; Hall, W.; Sedefov, R.; White, J.; Thomas, K.V.; Farrell, M.; Griffiths, P. New psychoactive substances: Challenges for drug surveillance, control, and public health responses. Lancet 2019, 394, 1668-1684. [CrossRef]

8. Meyer, M.R. New psychoactive substances: An overview on recent publications on their toxicodynamics and toxicokinetics. Arch. Toxicol. 2016, 90, 2421-2444. [CrossRef]

9. Evans-Brown, M.; Sedefov, R. New psychoactive substances: Driving greater complexity into the drug problem. Addiction 2017, 112, 36-38. [CrossRef] [PubMed]

10. United Nations Office on Drugs and Crime. UNODC Early Warning Advisory (EWA) on New Psychoactive Substances (NPS). Available online: https:/ / www.unodc.org/LSS/Home/NPS (accessed on 28 January 2021).

11. European Monitoring Centre for Drugs and Drug The EU Early Warning System on new psychoactive substances (NPS). Available online: https:/ /www.emcdda.europa.eu/publications/topic-overviews/eu-early-warning-system_en (accessed on 28 January 2021).

12. Smith, J.P.; Sutcliffe, O.B.; Banks, C.E. An overview of recent developments in the analytical detection of new psychoactive substances (NPSs). Analyst 2015, 140, 4932-4948. [CrossRef] [PubMed]

13. Graziano, S.; Orsolini, L.; Rotolo, M.C.; Tittarelli, R.; Schifano, F.; Pichini, S. Herbal Highs: Review on Psychoactive Effects and Neuropharmacology. Curr. Neuropharmacol. 2017, 15, 750-761. [CrossRef]

14. Souza, R.C.Z.; Zandonadi, F.S.; Freitas, D.P.; Tófoli, L.F.F.; Sussulini, A. Validation of an analytical method for the determination of the main ayahuasca active compounds and application to real ayahuasca samples from Brazil. J. Chromatogr. B Anal. Technol. Biomed. Life Sci. 2019, 1124, 197-203. [CrossRef] [PubMed] 
15. Peng, W.; Liu, Y.J.; Wu, N.; Sun, T.; He, X.Y.; Gao, Y.X.; Wu, C.J. Areca catechu L. (Arecaceae): A review of its traditional uses, botany, phytochemistry, pharmacology and toxicology. J. Ethnopharmacol. 2015, 164, 340-356. [CrossRef]

16. Gupta, P.C.; Warnakulasuriya, S. Global epidemiology of areca nut usage. Addict. Biol. 2002, 7, 77-83. [CrossRef] [PubMed]

17. Papke, R.L.; Horenstein, N.A.; Stokes, C. Nicotinic Activity of Arecoline, the Psychoactive Element of "Betel Nuts", Suggests a Basis for Habitual Use and Anti-Inflammatory Activity. PLoS ONE 2015, 10, e0140907. [CrossRef]

18. Coppola, M.; Mondola, R. Potential action of betel alkaloids on positive and negative symptoms of schizophrenia: A review. Nord. J. Psychiatry 2012, 66, 73-78. [CrossRef]

19. Taylor, R.F.H.; Al-Jarad, N.; John, L.M.E.; Barnes, N.C.; Conroy, D.M. Betel-nut chewing and asthma. Lancet 1992, 339, 1134-1136. [CrossRef]

20. Chen, Y.-C.; Lee, H.-C.; Lee, H.-H.; Su, H.-M.; Lin, T.-H.; Hsu, P.-C. Areca Nut Chewing Complicated with Non-Obstructive and Obstructive ST Elevation Myocardial Infarction. Acta Cardiol. Sin. 2016, 32, 103-107. [PubMed]

21. Salehi, B.; Konovalov, D.A.; Fru, P.; Kapewangolo, P.; Peron, G.; Ksenija, M.S.; Cardoso, S.M.; Pereira, O.R.; Nigam, M.; Nicola, S.; et al. Areca catechu-From farm to food and biomedical applications. Phyther. Res. 2020, 34, 2140-2158. [CrossRef] [PubMed]

22. Keshava Bhat, S.; Sarpangala, M.; Ashwin, D. Antilipidemic activity of arecanut, Areca catechu L.: A valuable herbal medicine. Int. J. Herb. Med. 2017, 5, 35-38.

23. Sreeramulu, D.; Reddy, C.V.K.; Chauhan, A.; Balakrishna, N.; Raghunath, M. Natural antioxidant activity of commonly consumed plant foods in India: Effect of domestic processing. Oxid. Med. Cell. Longev. 2013, 369479, 1-12. [CrossRef] [PubMed]

24. Wu, M.; Fang, M.; Hu, Y.; Wang, X. Four types of traditional Chinese medicine inducing epileptic seizures. Seizure 2012, 21, 311-315. [CrossRef] [PubMed]

25. Hamsar, M.N.; Ismail, S.; Mordi, M.N.; Ramanathan, S.; Mansor, S.M. Antioxidant activity and the effect of different parts of areca catechu extracts on Glutathione-S-Transferase activity in vitro. Free Radic. Antioxid. 2011, 1, 28-33. [CrossRef]

26. Wu, I.C.; Chen, P.H.; Wang, C.J.; Wu, D.C.; Tsai, S.M.; Chao, M.R.; Chen, B.H.; Lee, H.H.; Lee, C.H.; Ko, Y.C. Quantification of blood betel quid alkaloids and urinary 8-hydroxydeoxyguanosine in humans and their association with betel chewing habits. J. Anal. Toxicol. 2010, 34, 325-331. [CrossRef]

27. Pichini, S.; Pellegrini, M.; Pacifici, R.; Marcheil, E.; Murillo, J.; Puig, C.; Vall, O.; García-Algar, O. Quantification of arecoline (Areca nut alkaloid) in neonatal biological matrices by high-performance liquid chromatography/electrospray quadrupole mass spectrometry. Rapid Commun. Mass Spectrom. 2003, 17, 1958-1964. [CrossRef] [PubMed]

28. Krais, S.; Klima, M.; Huppertz, L.M.; Auwärter, V.; Altenburger, M.J.; Neukamm, M.A. Betel Nut Chewing in Iron Age Vietnam? Detection of Areca catechu Alkaloids in Dental Enamel. J. Psychoact. Drugs 2017, 49, 11-17. [CrossRef]

29. Franke, A.A.; Li, X.; Custer, L.J.; Lai, J.F. Chemical Markers for Short- and Long-Term Areca Nut Exposure. Subst. Use Misuse 2020, 55, 1395-1402. [CrossRef] [PubMed]

30. Lee, H.H.; Chen, L.Y.; Wang, H.L.; Chen, B.H. Quantification of salivary arecoline, arecaidine and N-methylnipecotic acid levels in volunteers by liquid chromatography-tandem mass spectrometry. J. Anal. Toxicol. 2015, 39, 714-719. [CrossRef] [PubMed]

31. Pellegrini, M.; Marchei, E.; Rossi, S.; Vagnarelli, F.; Durgbanshi, A.; García-Algar, Ó.; Vall, O.; Pichini, S. Liquid chromatography/electrospray ionization tandem mass spectrometry assay for determination of nicotine and metabolites, caffeine and arecoline in breast milk. Rapid Commun. Mass Spectrom. 2007, 21, 2693-2703. [CrossRef]

32. Marchei, E.; Durgbanshi, A.; Rossi, S.; Garcia-Algar, Ó.; Zuccaro, P.; Pichini, S. Determination of arecoline (areca nut alkaloid) and nicotine in hair by high-performance liquid chromatography/electrospray quadrupole mass spectrometry. Rapid Commun. Mass Spectrom. 2005, 19, 3416-3418. [CrossRef]

33. Austin, D.; Huáman, Z. A synopsis of Ipomoea (Convolvulaceae) in the Americas. Taxon 1996, 45, 3-38. [CrossRef]

34. Paulke, A.; Kremer, C.; Wunder, C.; Wurglics, M.; Schubert-Zsilavecz, M.; Toennes, S.W. Studies on the alkaloid composition of the Hawaiian Baby Woodrose Argyreia nervosa, a common legal high. Forensic Sci. Int. 2015, 249, 281-293. [CrossRef]

35. Chao, J.-M.; Der Marderosian, A.H. Ergoline alkaloidal constituents of hawaiian baby wood rose, argyreia nervosa (Burm. f.) bojer. J. Pharm. Sci. 1973, 62, 588-591. [CrossRef] [PubMed]

36. Larson, B.T.; Harmon, D.L.; Piper, E.L.; Griffis, L.M.; Bush, L.P. Alkaloid binding and activation of D2 dopamine receptors in cell culture. J. Anim. Sci. 1999, 77, 942. [CrossRef] [PubMed]

37. Modi, A.J.; Khadabadi, S.S.; Deokate, U.A.; Farooqui, I.A.; Deore, S.L.; Gangwani, M.R. Argyreia speciosa Linn. f.: Phytochemistry, pharmacognosy and pharmacological studies. J. Pharmacogn. Phyther. 2010, 2, 34-42.

38. Weber, J.M.; Ma, T.S. Microchemical investigations of medicinal plants. XIV—Identification of the alkaloids in the leaves of Ipomoea violacea using preparative thin layer chromatography and solid probe mass spectrometry. Mikrochim. Acta 1976, 65, 227-242. [CrossRef]

39. Paulke, A.; Kremer, C.; Wunder, C.; Toennes, S.W. Analysis of lysergic acid amide in human serum and urine after ingestion of Argyreia nervosa seeds. In Proceedings of the Analytical and Bioanalytical Chemistry; Springer: Berlin, Germany, 2012; Volume 404, pp. 531-538.

40. Simão, A.Y.; Gonçalves, J.; Duarte, A.P.; Barroso, M.; Cristóvão, A.C.; Gallardo, E. Toxicological Aspects and Determination of the Main Components of Ayahuasca: A Critical Review. Medicines 2019, 6, 106. [CrossRef]

41. Andrade, T.S.; de Oliveira, R.; da Silva, M.L.; Von Zuben, M.V.; Grisolia, C.K.; Domingues, I.; Caldas, E.D.; Pic-Taylor, A. Exposure to ayahuasca induces developmental and behavioral alterations on early life stages of zebrafish. Chem. Biol. Interact. 2018, 293, 133-140. [CrossRef] [PubMed] 
42. Gable, R.S. Risk assessment of ritual use of oral dimethyltryptamine (DMT) and harmala alkaloids. Addiction 2007, 102, 24-34. [CrossRef] [PubMed]

43. Ramachandran, P.; Zhang, N.; McLaughlin, W.B.; Luo, Y.; Handy, S.; Duke, J.A.; Vasquez, R.; Ottesen, A. Sequencing the vine of the soul: Full chloroplast genome sequence of Banisteriopsis caapi. Genome Announc. 2018, 6. [CrossRef] [PubMed]

44. Dos Santos, R.G.; Balthazar, F.M.; Bouso, J.C.; Hallak, J.E.C. The current state of research on ayahuasca: A systematic review of human studies assessing psychiatric symptoms, neuropsychological functioning, and neuroimaging. J. Psychopharmacol. 2016, 30, 1230-1247. [CrossRef]

45. dos Santos, R.G.; Osório, F.L.; Crippa, J.A.S.; Hallak, J.E.C. Antidepressive and anxiolytic effects of ayahuasca: A systematic literature review of animal and human studies. Rev. Bras. Psiquiatr. 2016, 38, 65-72. [CrossRef] [PubMed]

46. Riba, J.; Valle, M.; Urbano, G.; Yritia, M.; Morte, A.; Barbanoj, M.J. Human pharmacology of ayahuasca: Subjective and cardiovascular effects, monoamine metabolite excretion, and pharmacokinetics. J. Pharmacol. Exp. Ther. 2003, 306, 73-83. [CrossRef]

47. De Araujo, D.B.; Ribeiro, S.; Cecchi, G.A.; Carvalho, F.M.; Sanchez, T.A.; Pinto, J.P.; de Martinis, B.S.; Crippa, J.A.; Hallak, J.E.C.; Santos, A.C. Seeing with the eyes shut: Neural basis of enhanced imagery following ayahuasca ingestion. Hum. Brain Mapp. 2012, 33, 2550-2560. [CrossRef] [PubMed]

48. Riba, J.; Romero, S.; Grasa, E.; Mena, E.; Carrió, I.; Barbanoj, M.J. Increased frontal and paralimbic activation following ayahuasca, the pan-amazonian inebriant. Psychopharmacology 2006, 186, 93-98. [CrossRef]

49. Morales-García, J.A.; De La Fuente Revenga, M.; Alonso-Gil, S.; Rodríguez-Franco, M.I.; Feilding, A.; Perez-Castillo, A.; Riba, J The alkaloids of Banisteriopsis caapi, the plant source of the Amazonian hallucinogen Ayahuasca, stimulate adult neurogenesis in vitro. Sci. Rep. 2017, 7, 1-13. [CrossRef]

50. Hassan, Z.; Bosch, O.G.; Singh, D.; Narayanan, S.; Kasinather, B.V.; Seifritz, E.; Kornhuber, J.; Quednow, B.B.; Müller, C.P. Novel psychoactive substances-recent progress on neuropharmacological mechanisms of action for selected drugs. Front. Psychiatry 2017, 8, 152. [CrossRef] [PubMed]

51. Callaway, J.C.; Raymon, L.P.; Hearn, W.L.; McKenna, D.J.; Grob, C.S.; Brito, G.S.; Mash, D.C. Quantitation of N,N-dimethyltryptamine and harmala alkaloids in human plasma after oral dosing with ayahuasca. J. Anal. Toxicol. 1996, 20, 492-497. [CrossRef]

52. Gonçalves, J.; Luís, Â.; Gradillas, A.; García, A.; Restolho, J.; Fernández, N.; Domingues, F.; Gallardo, E.; Duarte, A.P. Ayahuasca Beverages: Phytochemical Analysis and Biological Properties. Antibiotics 2020, 9, 731. [CrossRef] [PubMed]

53. Simão, A.Y.; Gonçalves, J.; Gradillas, A.; García, A.; Restolho, J.; Fernández, N.; Rodilla, J.M.; Barroso, M.; Duarte, A.P.; Cristóvão, A.C.; et al. Evaluation of the Cytotoxicity of Ayahuasca Beverages. Molecules 2020, 25, 5594. [CrossRef]

54. De Osório, F.L.; Sanches, R.F.; Macedo, L.R.; dos Santos, R.G.; Maia-De-Oliveira, J.P.; Wichert-Ana, L.; de Araujo, D.B.; Riba, J.; Crippa, J.A.; Hallak, J.E. Antidepressant effects of a single dose of ayahuasca in patients with recurrent depression: A preliminary report. Rev. Bras. Psiquiatr. 2015, 37, 13-20. [CrossRef]

55. Sanches, R.F.; De Lima Osório, F.; Santos, R.G.D.; Macedo, L.R.H.; Maia-De-Oliveira, J.P.; Wichert-Ana, L.; De Araujo, D.B.; Riba, J.; Crippa, J.A.S.; Hallak, J.E.C. Antidepressant effects of a single dose of ayahuasca in patients with recurrent depression a SPECT study. J. Clin. Psychopharmacol. 2016, 36, 77-81. [CrossRef]

56. Santos, R.G.; Landeira-Fernandez, J.; Strassman, R.J.; Motta, V.; Cruz, A.P.M. Effects of ayahuasca on psychometric measures of anxiety, panic-like and hopelessness in Santo Daime members. J. Ethnopharmacol. 2007, 112, 507-513. [CrossRef] [PubMed]

57. Grob, C.S.; McKenna, D.J.; Callaway, J.C.; Brito, G.S.; Neves, E.S.; Oberlaender, G.; Saide, O.L.; Labigalini, E.; Tacla, C.; Miranda, C.T.; et al. Human psychopharmacology of hoasca, a plant hallucinogen used in ritual context in Brazil. J. Nerv. Ment. Dis. 1996, 184, 86-94. [CrossRef] [PubMed]

58. Thomas, G.; Lucas, P.; Capler, N.R.; Tupper, K.W.; Martin, G. Ayahuasca-assisted therapy for addiction: Results from a preliminary observational study in Canada. Curr. Drug Abus. Rev. 2013, 6, 30-42. [CrossRef] [PubMed]

59. Oliveira-Lima, A.J.; Santos, R.; Hollais, A.W.; Gerardi-Junior, C.A.; Baldaia, M.A.; Wuo-Silva, R.; Yokoyama, T.S.; Costa, J.L.; Malpezzi-Marinho, E.L.A.; Ribeiro-Barbosa, P.C.; et al. Effects of ayahuasca on the development of ethanol-induced behavioral sensitization and on a post-sensitization treatment in mice. Physiol. Behav. 2015, 142, 28-36. [CrossRef]

60. Da Silveira, D.X.; Grob, C.S.; de Rios, M.D.; Lopez, E.; Alonso, L.K.; Tacla, C.; Doering-Silveira, E. Ayahuasca in adolescence: A preliminary psychiatric assessment. J. Psychoact. Drugs 2005, 37, 129-133. [CrossRef]

61. Barbosa, P.C.R.; Cazorla, I.M.; Giglio, J.S.; Strassman, R.S. A six-month prospective evaluation of personality traits, psychiatric symptoms and quality of life in Ayahuasca-Naïve Subjects. J. Psychoact. Drugs 2009, 41, 205-212. [CrossRef] [PubMed]

62. Mcllhenny, E.H.; Riba, J.; Barbanoj, M.J.; Strassman, R.; Barker, S.A. Methodology for determining major constituents of ayahuasca and their metabolites in blood. Biomed. Chromatogr. 2012, 26, 301-313. [CrossRef]

63. Yritia, M.; Riba, J.; Ortuño, J.; Ramirez, A.; Castillo, A.; Alfaro, Y.; de la Torre, R.; Barbanoj, M.J. Determination of N, Ndimethyltryptamine and $\beta$-carboline alkaloids in human plasma following oral administration of Ayahuasca. J. Chromatogr. $B$ Anal. Technol. Biomed. Life Sci. 2002, 779, 271-281. [CrossRef]

64. Oliveira, C.D.R.; Okai, G.G.; Da Costa, J.L.; De Almeida, R.M.; Oliveira-Silva, D.; Yonamine, M. Determination of dimethyltryptamine and $\beta$-carbolines (ayahuasca alkaloids) in plasma samples by LC-MS/MS. Bioanalysis 2012, 4, 1731-1738. [CrossRef]

65. Mcilhenny, E.H.; Riba, J.; Barbanoj, M.J.; Strassman, R.; Barker, S.A. Methodology for and the determination of the major constituents and metabolites of the amazonian botanical medicine ayahuasca in human urine. Biomed. Chromatogr. 2011, 25, 970-984. [CrossRef] [PubMed] 
66. Riba, J.; Mcilhenny, E.H.; Bouso, J.C.; Barker, S.A. Metabolism and urinary disposition of N,N-dimethyltryptamine after oral and smoked administration: A comparative study. Drug Test. Anal. 2015, 7, 401-406. [CrossRef] [PubMed]

67. Pichini, S.; Marchei, E.; García-Algar, O.; Gomez, A.; Di Giovannandrea, R.; Pacifici, R. Ultra-high-pressure liquid chromatography tandem mass spectrometry determination of hallucinogenic drugs in hair of psychedelic plants and mushrooms consumers. J. Pharm. Biomed. Anal. 2014, 100, 284-289. [CrossRef] [PubMed]

68. Feyissa, A.M.; Kelly, J.P. A review of the neuropharmacological properties of khat. Prog. Neuro Psychopharmacol. Biol. Psychiatry 2008, 32, 1147-1166. [CrossRef]

69. Brenneisen, R.; Geisshüsler, S.; Schorno, X. Metabolism of cathinone to (-)-norephedrine and (-)-norpseudoephedrine. J. Pharm. Pharmacol. 1986, 38, 298-300. [CrossRef] [PubMed]

70. Sørensen, L.K. Determination of cathinones and related ephedrines in forensic whole-blood samples by liquid-chromatographyelectrospray tandem mass spectrometry. J. Chromatogr. B Anal. Technol. Biomed. Life Sci. 2011, 879, 727-736. [CrossRef]

71. Beyer, J.; Peters, F.T.; Kraemer, T.; Maurer, H.H. Detection and validated quantification of nine herbal phenalkylamines and methcathinone in human blood plasma by LC-MS/MS with electrospray ionization. J. Mass Spectrom. 2007, 42, 150-160. [CrossRef] [PubMed]

72. Toennes, S.W.; Kauert, G.F. Excretion and Detection of Cathinone, Cathine, and Phenylpropanolamine in Urine after Kath Chewing. Clin. Chem. 2002, 48, 1715-1719. [CrossRef] [PubMed]

73. Mohamed, K.M.; Al-Hazmi, A.H.; Alasiri, A.M.; Ali, M.E.S. A GC-MS Method for Detection and Quantification of Cathine, Cathinone, Methcathinone and Ephedrine in Oral Fluid. J. Chromatogr. Sci. 2016, 54, 1271-1276. [CrossRef]

74. Margalho, C.; Castanheira, A.; Real, F.C.; Gallardo, E.; López-Rivadulla, M. Determination of "new psychoactive substances" in postmortem matrices using microwave derivatization and gas chromatography-mass spectrometry. J. Chromatogr. B Anal. Technol. Biomed. Life Sci. 2016, 1020, 14-23. [CrossRef]

75. Margalho, C.; Almeida, P.; Rosado, T.; Corte-Real, F.; Gallardo, E. Determination of New Psychoactive Substances in Whole Blood Using Microwave Fast Derivatization and Gas Chromatography/Mass Spectrometry. J. Anal. Toxicol. 2020, 44, 92-102. [CrossRef]

76. Mahler, D.A. Anticholinergic poisoning from Jimson weed. J. Am. Coll. Emerg. Physicians 1976, 5, 440-442. [CrossRef]

77. Oerther, S.; Behrman, A.D.; Ketcham, S. Herbal hallucinations: Common abuse situations seen in the emergency department. J. Emerg. Nurs. 2010, 36, 594-596. [CrossRef]

78. Forrester, M.B. Jimsonweed (Datura stramonium) exposures in Texas, 1998-2004. J. Toxicol. Environ. Health Part A Curr. Issues 2006, 69, 1757-1762. [CrossRef] [PubMed]

79. Sutter, M.E.; Chenoweth, J.; Albertson, T.E. Alternative drugs of abuse. Clin. Rev. Allergy Immunol. 2014, 46, 3-18. [CrossRef]

80. Krenzelok, E.P. Aspects of datura poisoning and treatment. Clin. Toxicol. 2010, 48, 104-110. [CrossRef]

81. Gowdy, J.M. Stramonium intoxication: Review of symptomatology in 212 cases. JAMA J. Am. Med. Assoc. 1972, 221, 585-587. [CrossRef]

82. Levy, R. Jimson seed poisoning-A new hallucinogen on the horizon. J. Am. Coll. Emerg. Physicians 1977, 6, 58-61. [CrossRef]

83. Hanuš, L.O.; Řezanka, T.; Spížek, J.; Dembitsky, V.M. Substances isolated from Mandragora species. Phytochemistry 2005, 66, 2408-2417. [CrossRef] [PubMed]

84. Riley, S.C.E.; Blackman, G. Between prohibitions: Patterns and meanings of magic mushroom use in the UK. Subst. Use Misuse 2008, 43, 55-71. [CrossRef] [PubMed]

85. Suleiman, R.K.; Zarga, M.A.; Sabri, S.S. New withanolides from mandragora officinarum: First report of withanolides from the Genus Mandragora. Fitoterapia 2010, 81, 864-868. [CrossRef] [PubMed]

86. Frasca, T. Mandrake Toxicity. Arch. Intern. Med. 1997, 157, 2007. [CrossRef]

87. Vidal, F.; Templado, C.; Navarro, J.; Marina, S.; Egozcue, J. Meiotic and synaptonemal complex studies in a 14/21 translocation carrier. Int. J. Androl. 1982, 5, 21-26. [CrossRef]

88. Pietsch, J.; Günther, J.; Henle, T.; Dreßler, J. Simultaneous determination of thirteen plant alkaloids in a human specimen by SPE and HPLC. J. Sep. Sci. 2008, 31, 2410-2416. [CrossRef]

89. Carlier, J.; Guitton, J.; Romeuf, L.; Bévalot, F.; Boyer, B.; Fanton, L.; Gaillard, Y. Screening approach by ultra-high performance liquid chromatography-tandem mass spectrometry for the blood quantification of thirty-four toxic principles of plant origin. Application to forensic toxicology. J. Chromatogr. B Anal. Technol. Biomed. Life Sci. 2015, 975, 65-76. [CrossRef]

90. Namera, A.; Yashiki, M.; Hirose, Y.; Yamaji, S.; Tani, T.; Kojima, T. Quantitative analysis of tropane alkaloids in biological materials by gas chromatography-mass spectrometry. Forensic Sci. Int. 2002, 130, 34-43. [CrossRef]

91. Björnstad, K.; Beck, O.; Helander, A. A multi-component LC-MS/MS method for detection of ten plant-derived psychoactive substances in urine. J. Chromatogr. B Anal. Technol. Biomed. Life Sci. 2009, 877, 1162-1168. [CrossRef]

92. Halpern, J.H.; Sewell, R.A. Hallucinogenic botanicals of America: A growing need for focused drug education and research. Life Sci. 2005, 78, 519-526. [CrossRef]

93. Carstairs, S.D.; Cantrell, F.L. Peyote and mescaline exposures: A 12-year review of a statewide poison center database. Clin. Toxicol. 2010, 48, 350-353. [CrossRef]

94. Forsyth, B.; Machado, L.; Jowett, T.; Jakobi, H.; Garbe, K.; Winter, H.; Glue, P. Effects of low dose ibogaine on subjective mood state and psychological performance. J. Ethnopharmacol. 2016, 189, 10-13. [CrossRef]

95. Halberstadt, A.L.; Geyer, M.A. Multiple receptors contribute to the behavioral effects of indoleamine hallucinogens. Neuropharmacology 2011, 61, 364-381. [CrossRef] 
96. Hollister, L.E.; Hartman, A.M. Mescaline, lysergic acid diethylamide and psilocybin: Comparison of clinical syndromes, effects on color perception and biochemical measures. Compr. Psychiatry 1962, 3, 235-241. [CrossRef]

97. Johnson, M.W.; Andrew Sewell, R.; Griffiths, R.R. Psilocybin dose-dependently causes delayed, transient headaches in healthy volunteers. Drug Alcohol Depend. 2012, 123, 132-140. [CrossRef] [PubMed]

98. Hermle, L.; Fünfgeld, M.; Oepen, G.; Botsch, H.; Borchardt, D.; Gouzoulis, E.; Fehrenbach, R.A.; Spitzer, M. Mescaline-induced psychopathological, neuropsychological, and neurometabolic effects in normal subjects: Experimental psychosis as a tool for psychiatric research. Biol. Psychiatry 1992, 32, 976-991. [CrossRef]

99. Hollister, L.E.; Sjoberg, B.M. Clinical syndromes and biochemical alterations following mescaline, lysergic acid diethylamide, psilocybin and a combination of the three psychotomimetic drugs. Compr. Psychiatry 1964, 5, 170-178. [CrossRef]

100. Dinis-Oliveira, R.J.; Pereira, C.L.; da Silva, D.D. Pharmacokinetic and Pharmacodynamic Aspects of Peyote and Mescaline: Clinical and Forensic Repercussions. Curr. Mol. Pharmacol. 2018, 12, 184-194. [CrossRef]

101. Singh, D.; Müller, C.P.; Vicknasingam, B.K.; Mansor, S.M. Social Functioning of Kratom (Mitragyna speciosa) Users in Malaysia. J. Psychoact. Drugs 2015, 47, 125-131. [CrossRef]

102. Singh, D.; Narayanan, S.; Vicknasingam, B. Traditional and non-traditional uses of Mitragynine (Kratom): A survey of the literature. Brain Res. Bull. 2016, 126, 41-46. [CrossRef] [PubMed]

103. Brown, P.N.; Lund, J.A.; Murch, S.J. A botanical, phytochemical and ethnomedicinal review of the genus Mitragyna korth: Implications for products sold as kratom. J. Ethnopharmacol. 2017, 202, 302-325. [CrossRef]

104. Vicknasingam, B.; Narayanan, S.; Beng, G.T.; Mansor, S.M. The informal use of ketum (Mitragyna speciosa) for opioid withdrawal in the northern states of peninsular Malaysia and implications for drug substitution therapy. Int. J. Drug Policy 2010, 21, 283-288. [CrossRef]

105. Boyer, E.W.; Babu, K.M.; Adkins, J.E.; McCurdy, C.R.; Halpern, J.H. Self-treatment of opioid withdrawal using kratom (Mitragynia speciosa korth). Addiction 2008, 103, 1048-1050. [CrossRef]

106. Cinosi, E.; Martinotti, G.; Simonato, P.; Singh, D.; Demetrovics, Z.; Roman-Urrestarazu, A.; Bersani, F.S.; Vicknasingam, B.; Piazzon, G.; Li, J.H.; et al. Following "the Roots" of Kratom (Mitragyna speciosa): The Evolution of an Enhancer from a Traditional Use to Increase Work and Productivity in Southeast Asia to a Recreational Psychoactive Drug in Western Countries. Biomed Res. Int. 2015, 2015. [CrossRef]

107. Warner, M.L.; Kaufman, N.C.; Grundmann, O. The pharmacology and toxicology of kratom: From traditional herb to drug of abuse. Int. J. Leg. Med. 2016, 130, 127-138. [CrossRef]

108. Suhaimi, F.W.; Yusoff, N.H.M.; Hassan, R.; Mansor, S.M.; Navaratnam, V.; Müller, C.P.; Hassan, Z. Neurobiology of Kratom and its main alkaloid mitragynine. Brain Res. Bull. 2016, 126, 29-40. [CrossRef]

109. Ahmad, K.; Aziz, Z. Mitragyna speciosa use in the northern states of Malaysia: A cross-sectional study. J. Ethnopharmacol. 2012, 141, 446-450. [CrossRef] [PubMed]

110. Meireles, V.; Rosado, T.; Barroso, M.; Soares, S.; Gonçalves, J.; Luís, Â.; Caramelo, D.; Simão, A.; Fernández, N.; Duarte, A.; et al. Mitragyna speciosa: Clinical, Toxicological Aspects and Analysis in Biological and Non-Biological Samples. Medicines 2019, 6, 35. [CrossRef] [PubMed]

111. Shellard, E.J.; Phillipson, J.D.; Gupta, D. The Mitragyna species of Asia. XV. The alkaloids from the bark of Mitragyna parvifolia (Roxb.) Korth and a possible biogenetic route for the oxindole alkaloids. Planta Med. 1969, 17, 146-163. [CrossRef]

112. Ujvary, I. Kratom and Other Mitragynines: The Chemistry and Pharmacology of Opioids from a Non-Opium Source. J. Addict. Res. Ther. 2015, 6, 1-2. [CrossRef]

113. Hassan, Z.; Muzaimi, M.; Navaratnam, V.; Yusoff, N.H.M.; Suhaimi, F.W.; Vadivelu, R.; Vicknasingam, B.K.; Amato, D.; von Hörsten, S.; Ismail, N.I.W.; et al. From Kratom to mitragynine and its derivatives: Physiological and behavioural effects related to use, abuse, and addiction. Neurosci. Biobehav. Rev. 2013, 37, 138-151. [CrossRef] [PubMed]

114. Yusoff, N.H.M.; Mansor, S.M.; Müller, C.P.; Hassan, Z. Opioid receptors mediate the acquisition, but not the expression of mitragynine-induced conditioned place preference in rats. Behav. Brain Res. 2017, 332, 1-6. [CrossRef] [PubMed]

115. Lu, J.; Wei, H.; Wu, J.; Jamil, M.F.A.; Tan, M.L.; Adenan, M.I.; Wong, P.; Shim, W. Evaluation of the Cardiotoxicity of Mitragynine and Its Analogues Using Human Induced Pluripotent Stem Cell-Derived Cardiomyocytes. PLoS ONE 2014, 9, e115648. [CrossRef]

116. Matsumoto, K.; Yamamoto, L.T.; Watanabe, K.; Yano, S.; Shan, J.; Pang, P.K.T.; Ponglux, D.; Takayama, H.; Horie, S. Inhibitory effect of mitragynine, an analgesic alkaloid from Thai herbal medicine, on neurogenic contraction of the vas deferens. Life Sci. 2005, 78, 187-194. [CrossRef] [PubMed]

117. Utar, Z.; Majid, M.I.A.; Adenan, M.I.; Jamil, M.F.A.; Lan, T.M. Mitragynine inhibits the COX-2 mRNA expression and prostaglandin E 2 production induced by lipopolysaccharide in RAW264.7 macrophage cells. J. Ethnopharmacol. 2011, 136, 75-82. [CrossRef] [PubMed]

118. Farah Idayu, N.; Taufik Hidayat, M.; Moklas, M.A.M.; Sharida, F.; Nurul Raudzah, A.R.; Shamima, A.R.; Apryani, E. Antidepressant-like effect of mitragynine isolated from Mitragyna speciosa Korth in mice model of depression. Phytomedicine 2011, 18, 402-407. [CrossRef]

119. Nelsen, J.L.; Lapoint, J.; Hodgman, M.J.; Aldous, K.M. Seizure and Coma Following Kratom (Mitragynina speciosa Korth) Exposure. J. Med. Toxicol. 2010, 6, 424-426. [CrossRef]

120. Davidson, L.; Rawat, M.; Stojanovski, S.; Chandrasekharan, P. Natural drugs, not so natural effects: Neonatal abstinence syndrome secondary to "kratom". J. Neonatal. Perinat. Med. 2019, 12, 109-112. [CrossRef] [PubMed] 
121. Lee, M.J.; Ramanathan, S.; Mansor, S.M.; Yeong, K.Y.; Tan, S.C. Method validation in quantitative analysis of phase I and phase II metabolites of mitragynine in human urine using liquid chromatography-tandem mass spectrometry. Anal. Biochem. 2018, 543, 146-161. [CrossRef]

122. Basiliere, S.; Bryand, K.; Kerrigan, S. Identification of five Mitragyna alkaloids in urine using liquid chromatographyquadrupole/time of flight mass spectrometry. J. Chromatogr. B Anal. Technol. Biomed. Life Sci. 2018, 1080, 11-19. [CrossRef]

123. Le, D.; Goggin, M.M.; Janis, G.C. Analysis of Mitragynine and Metabolites in Human Urine for Detecting the Use of the Psychoactive Plant Kratom. J. Anal. Toxicol. 2012, 36, 616-625. [CrossRef]

124. Fu, H. A Mass Spectrometric Study of Kratom Compounds by Direct Infusion Electrospray Ionization Triple Quadrupole Mass Spectrometry. Detection 2016, 4, 66-72. [CrossRef]

125. Pantano, F.; Tittarelli, R.; Mannocchi, G.; Zaami, S.; Ricci, S.; Giorgetti, R.; Terranova, D.; Busardò, F.; Marinelli, E. Hepatotoxicity Induced by "the 3Ks": Kava, Kratom and Khat. Int. J. Mol. Sci. 2016, 17, 580. [CrossRef] [PubMed]

126. Teschke, R.; Qiu, S.X.; Lebot, V. Herbal hepatotoxicity by kava: Update on pipermethystine, flavokavain B, and mould hepatotoxins as primarily assumed culprits. Dig. Liver Dis. 2011, 43, 676-681. [CrossRef]

127. Villain, M.; Cirimele, V.; Tracqui, A.; Ricaut, F.X.; Ludes, B.; Kintz, P. Testing for kavain in human hair using gas chromatographytandem mass spectrometry. J. Chromatogr. B Anal. Technol. Biomed. Life Sci. 2003, 798, 351-354. [CrossRef]

128. Tarbah, F.; Barguil, Y.; Müller, C.; Rickert, A.; Weinmann, W.; Nour, M.; Kintz, P.; Daldrup, T. Chromatographic hair analysis for natural kavalactones and their metabolites. A preliminary study. Ann. Toxicol. Anal. 2013, 25, 109-119. [CrossRef]

129. Wang, Y.; Eans, S.O.; Stacy, H.M.; Narayanapillai, S.C.; Sharma, A.; Fujioka, N.; Haddad, L.; McLaughlin, J.; Avery, B.A.; Xing, C. A stable isotope dilution tandem mass spectrometry method of major kavalactones and its applications. PLoS ONE 2018, 13. [CrossRef]

130. Tarbah, F.; Mahler, H.; Kardel, B.; Weinmann, W.; Hafner, D.; Daldrup, T. Kinetics of kavain and its metabolites after oral application. J. Chromatogr. B Anal. Technol. Biomed. Life Sci. 2003, 789, 115-130. [CrossRef]

131. Halpern, J.H. Hallucinogens and dissociative agents naturally growing in the United States. Pharmacol. Ther. 2004, 102, 131-138. [CrossRef] [PubMed]

132. Vollenweider, F.X.; Kometer, M. The neurobiology of psychedelic drugs: Implications for the treatment of mood disorders. Nat. Rev. Neurosci. 2010, 11, 642-651. [CrossRef]

133. Harries, A.D.; Evans, V. Sequelae of a "magic mushroom banquet.". Postgrad. Med. J. 1981, 57, 571-572. [CrossRef] [PubMed]

134. Wittmann, M.; Carter, O.; Hasler, F.; Cahn, B.R.; Grimberg, U.; Spring, P.; Hell, D.; Flohr, H.; Vollenweider, F.X. Effects of psilocybin on time perception and temporal control of behaviour in humans. J. Psychopharmacol. 2007, 21, 50-64. [CrossRef]

135. Griffiths, R.R.; Johnson, M.W.; Richards, W.A.; Richards, B.D.; McCann, U.; Jesse, R. Psilocybin occasioned mystical-type experiences: Immediate and persisting dose-related effects. Psychopharmacol. 2011, 218, 649-665. [CrossRef] [PubMed]

136. Vargas, A.S.; Luís, Â.; Barroso, M.; Gallardo, E.; Pereira, L. Psilocybin as a New Approach to Treat Depression and Anxiety in the Context of Life-Threatening Diseases-A Systematic Review and Meta-Analysis of Clinical Trials. Biomedicines 2020, 8, 331. [CrossRef]

137. Pellegrini, M.; Rotolo, M.C.; Marchei, E.; Pacifici, R.; Saggio, F.; Pichini, S. Magic truffles or Philosopher's stones: A legal way to sell psilocybin? Drug Test. Anal. 2013, 5, 182-185. [CrossRef]

138. Kamata, T.; Nishikawa, M.; Katagi, M.; Tsuchihashi, H. Optimized glucuronide hydrolysis for the detection of psilocin in human urine samples. J. Chromatogr. B Anal. Technol. Biomed. Life Sci. 2003, 796, 421-427. [CrossRef]

139. Kamata, T.; Nishikawa, M.; Katagi, M.; Tsuchihashi, H. Direct detection of serum psilocin glucuronide by LC/MS and LC/MS/MS: Time-courses of total and free (unconjugated) psilocin concentrations in serum specimens of a "magic mushroom" user. Forensic Toxicol. 2006, 24, 36-40. [CrossRef]

140. Valdés, L.J.; Díaz, J.; Paul, A.G. Ethnopharmacology of ska María Pastora (Salvia divinorum, Epling AND Játiva-M.). J. Ethnopharmacol. 1983, 7, 287-312. [CrossRef]

141. Medana, C.; Massolino, C.; Pazzi, M.; Baiocchi, C. Determination of salvinorins and divinatorins inSalvia divinorum leaves by liquid chromatography/multistage mass spectrometry. Rapid Commun. Mass Spectrom. 2006, 20, 131-136. [CrossRef]

142. Roth, B.L.; Baner, K.; Westkaemper, R.; Siebert, D.; Rice, K.C.; Steinberg, S.A.; Ernsberger, P.; Rothman, R.B. Salvinorin A: A potent naturally occurring nonnitrogenous $\mathrm{k}$ opioid selective agonist. Proc. Natl. Acad. Sci. USA. 2002, 99, 11934-11939. [CrossRef]

143. Paudel, M.K.; Shirota, O.; Sakamoto, S.; Morimoto, S.; Tanaka, H. An immunochromatographic assay for rapid etection of salvinorin A. J. Immunoass. Immunochem. 2017, 38, 438-448. [CrossRef]

144. Paudel, M.K.; Shirota, O.; Sasaki-Tabata, K.; Tanaka, H.; Sekita, S.; Morimoto, S. Development of an Enzyme Immunoassay Using a Monoclonal Antibody against the Psychoactive Diterpenoid Salvinorin, A. J. Nat. Prod. 2013, 76, 1654-1660. [CrossRef]

145. Braida, D.; Limonta, V.; Capurro, V.; Fadda, P.; Rubino, T.; Mascia, P.; Zani, A.; Gori, E.; Fratta, W.; Parolaro, D.; et al. Involvement of K-Opioid and Endocannabinoid System on Salvinorin A-Induced Reward. Biol. Psychiatry 2008, 63, 286-292. [CrossRef]

146. Braida, D.; Capurro, V.; Zani, A.; Rubino, T.; Viganò, D.; Parolaro, D.; Sala, M. Potential anxiolytic-And antidepressantlike effects of salvinorin A, the main active ingredient of Salvia divinorum, in rodents. Br. J. Pharmacol. 2009, 157, 844-853. [CrossRef] [PubMed]

147. Ebner, S.R.; Roitman, M.F.; Potter, D.N.; Rachlin, A.B.; Chartoff, E.H. Depressive-like effects of the kappa opioid receptor agonist salvinorin A are associated with decreased phasic dopamine release in the nucleus accumbens. Psychopharmacology 2010, 210, 241-252. [CrossRef] 
148. Fichna, J.; Dicay, M.; Lewellyn, K.; Janecka, A.; Zjawiony, J.K.; MacNaughton, W.K.; Storr, M.A. Salvinorin A has antiinflammatory and antinociceptive effects in experimental models of colitis in mice mediated by KOR and CB1 receptors. Inflamm. Bowel Dis. 2012, 18, 1137-1145. [CrossRef]

149. Hanes, K.R. Antidepressant effects of the herb salvia divinorum: A case report [12]. J. Clin. Psychopharmacol. 2001, 21,634-635. [CrossRef] [PubMed]

150. Kivell, B.M.; Ewald, A.W.M.; Prisinzano, T.E. Salvinorin A analogs and other kappa-opioid receptor compounds as treatments for cocaine abuse. Adv. Pharmacol. 2014, 69, 481-511. [PubMed]

151. McCurdy, C.R.; Sufka, K.J.; Smith, G.H.; Warnick, J.E.; Nieto, M.J. Antinociceptive profile of salvinorin A, a structurally unique kappa opioid receptor agonist. Pharmacol. Biochem. Behav. 2006, 83, 109-113. [CrossRef] [PubMed]

152. Su, D.; Riley, J.; Armstead, W.M.; Liu, R. Salvinorin a pretreatment preserves cerebrovascular autoregulation after brain hypoxic/ischemic injury via extracellular signal-regulated kinase/mitogen-activated protein kinase in piglets. Anesth. Analg. 2012, 114, 200-204. [CrossRef]

153. Xin, J.; Zhang, Y.; He, Z.; Wang, Z. Highly selective non-opioid kappa opioid receptor (KOR) agonist salvinorin A protects against forebrain ischemia-induced brain injury in rats. Brain Res. 2016, 1637, 168-176. [CrossRef]

154. Zhang, Y.; Butelman, E.R.; Schlussman, S.D.; Ho, A.; Kreek, M.J. Effects of the plant-derived hallucinogen salvinorin A on basal dopamine levels in the caudate putamen and in a conditioned place aversion assay in mice: Agonist actions at kappa opioid receptors. Psychopharmacology 2005, 179, 551-558. [CrossRef] [PubMed]

155. Cruz, A.; Domingos, S.; Gallardo, E.; Martinho, A. A unique natural selective kappa-opioid receptor agonist, salvinorin A, and its roles in human therapeutics. Phytochemistry 2017, 137, 9-14. [CrossRef] [PubMed]

156. Silva, A.; Simão, A.; Gonçalves, J.; Caramelo, D.; Soares, S.; Luís, Â.; Rosado, T.; Barroso, M.; Duarte, A.P.; Gallardo, E. Salvia Divinorum: Beyond Its Therapeutic Uses. In Salvia: Chemistry and Effects; Villalobos, J.R.R., Ed.; Nova Publisher: Hauppauge, NY, USA, 2020; Volume 1, pp. 175-211. ISBN 978-1-53617-819-7.

157. Barnes, B.B.; Snow, N.H. Analysis of Salvinorin A in plants, water, and urine using solid-phase microextraction-comprehensive two-dimensional gas chromatography-time of flight mass spectrometry. J. Chromatogr. A 2012, 1226, 110-115. [CrossRef]

158. McDonough, P.C.; Holler, J.M.; Vorce, S.P.; Bosy, T.Z.; Magluilo, J.; Past, M.R. The Detection and Quantitative Analysis of the Psychoactive Component of Salvia divinorum, Salvinorin A, in Human Biological Fluids Using Liquid Chromatography-Mass Spectrometry*. J. Anal. Toxicol. 2008, 32, 417-421. [CrossRef] [PubMed]

159. Pichini, S.; Abanades, S.; Farré, M.; Pellegrini, M.; Marchei, E.; Pacifici, R.; De La Torre, R.; Zuccaro, P. Quantification of the plant-derived hallucinogen Salvinorin A in conventional and non-conventional biological fluids by gas chromatography/mass spectrometry after Salvia divinorum smoking. Rapid Commun. Mass Spectrom. 2005, 19, 1649-1656. [CrossRef]

160. Moreno, I.; Da Fonseca, B.; Oppolzer, D.; Martinho, A.; Barroso, M.; Cruz, A.; Queiroz, J.A.; Gallardo, E. Analysis of Salvinorin A in urine using microextraction in packed syringe and GC-MS/MS. Bioanalysis 2013, 5, 661-668. [CrossRef]

161. Margalho, C.; Gallardo, E.; Castanheira, A.; Vieira, D.N.; López-Rivadulla, M.; Real, F.C. A validated procedure for detection and quantitation of salvinorin a in pericardial fluid, vitreous humor, whole blood and plasma using solid phase extraction and gas chromatography-mass spectrometry. J. Chromatogr. A 2013, 1304, 203-210. [CrossRef]

162. Alper, K.R.; Stajić, M.; Gill, J.R. Fatalities Temporally Associated with the Ingestion of Ibogaine. J. Forensic Sci. 2012, 57, 398-412. [CrossRef]

163. Paškulin, R.; Jamnik, P.; Danevčič, T.; Koželj, G.; Krašovec, R.; Krstić-Milošević, D.; Blagojević, D.; Štrukelj, B. Metabolic plasticity and the energy economizing effect of ibogaine, the principal alkaloid of Tabernanthe iboga. J. Ethnopharmacol. 2012, 143, 319-324. [CrossRef]

164. Alper, K.R. Ibogaine: A review. Alkaloids Chem. Biol. 2001, 56, 1-38. [PubMed]

165. Glick, S.D.; Maisonneuve, I.M.; Szumlinski, K.K. Mechanisms of action of ibogaine: Relevance to putative therapeutic effects and development of a safer iboga alkaloid congener. Alkaloids Chem. Biol. 2001, 56, 39-53.

166. Goutarel, R.; Gollnhofer, O.; Sillans, R. Pharmacodynamics and therapeutic applications of iboga and ibogaine. Psychedelic Monogr. 1993, 6, 71-111.

167. Kontrimavičiut, V.; Larroque, M.; Briedis, V.; Margout, D.; Bressolle, F. Quantitation of ibogaine and 12-hydroxyibogamine in human plasma by liquid chromatography with fluorimetric detection. J. Chromatogr. B Anal. Technol. Biomed. Life Sci. 2005, 822, 285-293. [CrossRef] [PubMed] 